\title{
Diversity of large ornithopod dinosaurs in the upper Hauterivian-lower Barremian (Lower Cretaceous) of Teruel (Spain): a morphometric approach
}

\author{
Francisco J. VERDU', Alberto COBOS, Rafael ROYO-TORRES \& Luis ALCALÁ
}

Fundación Conjunto Paleontológico de Teruel-Dinópolis, Av. Sagunto, S/N, 44002, Teruel (Spain); verdu@fundaciondinopolis.org, cobos@dinopolis.com,royo@dinopolis.com, alcala@dinopolis.com

*Corresponding author

Verdú, F.J., Cobos, A., Royo-Torres, R. \& Alcalá, L. 2019. Diversity of large ornithopod dinosaurs in the upper Hauterivian-lower Barremian (Lower Cretaceous) of Teruel (Spain): a morphometric approach. [Diversidad de grandes dinosaurios ornitópodos en el Hauteriviense superior-Barremiense inferior (Cretácico Inferior) de Teruel (España): una aproximación morfométrica]. Spanish Journal of Palaeontology, 34 (2), 269-288.

Manuscript received 12 December 2018

Manuscript accepted 13 May 2019 https://doi 10.7203/sjp.34.2.16116

(C) Sociedad Española de Paleontología ISSN 2255-0550

\begin{abstract}
We report some large ornithopod vertebrae from two upper Hauterivian-lower Barremian (Lower Cretaceous) localities in El Castellar (Maestrazgo Basin, Teruel, Spain). These fossils have been studied systematically as well as morphometrically using a multivariate analysis in order to analyse the diversity of the sample. In fact, principal component analysis has been demonstrated as an useful tool for establishing affinities in isolated iguanodontian vertebrae, at least when size effect is not removed from the analysed dataset. As result of this study, two large indeterminate styracosternans are distinguished in the sample: a large one with platycoelus anterior caudal vertebrae related to the genera Magnamanus and Iguanodon, and a middle-sized one with longer-than-high dorsal vertebrae and amphicoelus anterior caudal vertebrae related to Morelladon. Such diversity of large ornithopods observed in the upper Hauterivian-lower Barremian of the Maestrazgo Basin is similar to that previously observed in western Cameros Basin and it demonstrates the presence of at least two different forms of styracosternan in this stratigraphic range of the Iberian Peninsula.
\end{abstract}

\section{RESUMEN}

En este trabajo describimos y analizamos varias vértebras de grandes ornitópodos procedentes de dos yacimientos situados en el Hauteriviense superior-Barremiense inferior (Cretácico Inferior) de El Castellar (Cuenca del Maestrazgo, Teruel, España). Los fósiles se han estudiado tanto sistemática como morfométricamente empleando un análisis multivariante en el último caso, con el fin de analizar la diversidad de la muestra. De hecho, el análisis de componentes principales realizado ha demostrado ser una herramienta útil para establecer afinidades en vertebras aisladas de iguanodontios, al menos cuando el efecto del tamaño no se elimina del conjunto de datos analizados. Como resultado, dos grandes estiracosternos indeterminados se distinguen en la muestra: uno grande, relacionado con los géneros Magnamanus e Iguanodon, con vértebras caudales anteriores platicélicas, y otro de tamaño mediano, relacionado con Morelladon, con centros vertebrales dorsales más largos que altos y vértebras caudales anteriores anficélicas. Esta diversidad de grandes ornitópodos en el Hauteriviense superior-Barremiense inferior de la Cuenca del Maestrazgo es similar a la observada en el margen occidental de la Cuenca de Cameros y demuestra la 
Keywords: Peñagolosa sub-basin, El Castellar Formation, Ornithopoda, Styracosterna, Principal Components Analysis. presencia de al menos dos formas de estiracosternos en este intervalo estratigráfico en la Península Ibérica.

Palabras Clave: Subcuenca de Peñagolosa, Formación El Castellar, Ornithopoda, Styracosterna, Análisis de Componentes Principales.

\section{INTRODUCTION}

The fossils of large ornithopods are the most abundant among those belonging to dinosaurs in the Lower Cretaceous of the Iberian Peninsula (Pereda-Suberbiola et al., 2012; Gasca et al., 2014; Gasulla, 2015; Verdú, 2017; Alcalá et al., 2018). Based on current knowledge, the diversity of this type of dinosaur (all of which are considered Styracosterna) in this stratigraphic range is composed of Magnamanus soriaensis Fuentes et al., 2016 in the upper Hauterivian-lower Barremian of Soria province (Fuentes et al., 2016); Iguanodon galvensis Verdú et al., 2015 in the lower Barremian of Teruel province (Verdú et al., 2015); Iguanodon bernissartensis Boulenger in Van Beneden, 1881, Mantellisaurus atherfieldensis (Hooley, 1925), and Morelladon beltrani Gasulla et al., 2015 in the upper Barremian of Cuenca (with the exception of the last taxon) and Castellón provinces (Sanz et al., 1982; Llandres et al., 2013; Gasulla et al., 2014, 2015; Gasulla, 2015; Sanguino \& Buscalioni, 2018); and Proa valdearinnoensis McDonald et al., 2012 in the Albian of Teruel province (McDonald et al., 2012). In addition, another styracosternan described in the lower Barremian of Teruel province, 'Delapparentia turolensis' Ruiz-Omeñaca, 2011, is generally considered a nomen dubium (Norman, 2015; Verdú et al., 2017).

While the robust basal styracosternan Magnamanus is the unique large ornithopod recognised in the upper Hauterivian-lower Barremian (western part of the Cameros Basin, Soria province), some dorsal vertebrae with elongate neural spines found in deposits of similar age from the nearby Burgos province (Pereda-Suberbiola et al., 2011) potentially represent other taxon, possibly related to the sail-backed styracosternan Morelladon according to their proportions (Gasulla et al., 2015). Additionally, other fossils from the western part of the Cameros Basin have also been related to the robustly built genus Iguanodon in the upper Hauterivian-lower Barremian (Torcida Fernández-Baldor et al., 2006 after Gasca et al., 2014).

In the western Maestrazgo Basin, the upper Hauterivianlower Barremian outcrops of the Areniscas y Calizas de El Castellar Formation (Salas, 1987; Martín-Closas, 1989) have yielded many diverse dinosaur fossils, including those of large ornithopods (e.g., Luque et al., 2006; Gasca et al., 2009; Gasca, 2011; Cobos et al., 2012; Guerrero \& Cobos, 2017). Despite this, ornithopods from this lithostratigraphic unit have been scarcely studied, likely due to the fragmentary conditions of their remains.

In this work, we present the results of a study of an assemblage of vertebral centra recovered from two sites (CT-16 and CT-17) found in the surroundings of El Castellar village (southern margin of the Maestrazgo Basin, Teruel, Spain) in outcrops of the El Castellar Formation. In addition to a traditional systematic study of these fossils, a morphometric analysis of the vertebrae has also been conducted to explore vertebral diversity throughout the sample. In ornithopods, these methods have been demonstrated as particularly useful in quantifying morphological differences in functional studies of the axial and appendicular skeleton (e.g., Fearon \& Varrichio, 2015) and investigating the evolution of either a particular trait (e.g., VanBuren \& Bonnan, 2013) or a specific taxonomic group (e.g., Prieto-Márquez, 2010). Additionally, they are used to identify intraspecific (Verdú et al., 2017) and interspecific variation (e.g., Brink et al., 2014). Finally, morphometric methods have also been employed to test taxonomic affinities of isolated remains (e.g., Barrett et $a l ., 2014$ ) and explore diversity in fossil assemblages (e.g., Blanco et al., 2015), as in the present study.

Hence, the aims of this work are: (a) to anatomically describe the large ornithopod vertebral remains recovered in CT-16 and CT-17, the latter having been previously studied by Cobos et al. (2012); (b) to compare the anatomical features of these fossils with those of other large European ornithopods; (c) to analyse and quantify through morphometric methods the affinities of these fragmentary fossils with other European iguanodontians; and (d) to discuss the implications of these findings for the current knowledge of ornithopod diversity in the Lower Cretaceous of the Iberian Peninsula.

\subsection{Institutional abbreviations}

GPIT - Institut für Geowissenschaften, Tübingen, Germany.

IWCMS - Dinosaur Isle, Sandown, United Kingdom. MAP - Museo Aragonés de Paleontología, Fundación Conjunto Paleontológico de Teruel-Dinópolis, Teruel, Spain.

MDS - Museo de Dinosaurios de Salas de los Infantes, Salas de los Infantes, Spain. 
MNS - Museo Numantino de Soria, Soria, Spain.

RBINS - Royal Belgian Institute of Natural Sciences, Brussels, Belgium.

SHN - Sociedade de Historia Natural, Torres Vedras, Portugal.

\subsection{Other abbreviations}

CMP-MS - Mas de la Parreta Quarry-Mas de Sabater site, Morella, Spain (the material under these initials is currently housed at Museo de la Valltorta, Tirig, Spain)

CT - El Castellar site, El Castellar, Teruel, Spain.

DS - Las Dehesillas site, Aliaga, Spain (the material under these initials is currently housed at Museo Aragonés de Paleontología, Fundación Conjunto Paleontológico de Teruel-Dinópolis, Teruel, Spain).

\section{GEOGRAPHIC AND GEOLOGICAL SETTINGS}

Dinosaur sites CT-16 and CT-17 were found in the southern section of El Castellar village. Geographically, this town is located in the southeast region of the Iberian Range and $40 \mathrm{~km}$ east of the city of Teruel (Fig. 1a).

Geologically, the area of El Castellar lies in the Peñagolosa sub-basin (southern margin of the Maestrazgo
Basin) (Salas \& Guimerá, 1996). Both CT-16 and C-17 fossils were found ex situ in two separate and clearly differentiated concentrations where the El Castellar Formation outcrops (Figs 1b-1c). This lithostratigraphic unit was defined in the Peñagolosa sub-basin by Salas (1987) and uncomfortably overlies either the Villar del Arzobispo Formation (Kimmeridgian-Tithonian) or the Mora de Rubielos Formation (upper Berriasian-lower Valanginian) (Campos-Soto et al., 2017). In this area, the El Castellar Formation is overlain by the Camarillas Formation (lower Barremian) (Campos-Soto et al., 2017). Broadly, the El Castellar Formation is divided into two stages in the Peñagolosa sub-basin (Cobos et al., 2012). The lower stage generally consists of clays intercalated with channelled bodies of sandstones, which are interpreted as alluvial sediments in an alluvial plain crossed by channels. The upper stage represents lacustrine deposits composed of a marl level with gypsum and, after that, marls alternating with limestones containing numerous fossils of freshwater flora and fauna. The location of CT-16 and CT-17 and the clayish matrix partially covering some fossils indicates that they come from a grey or pinkish clay layer that belongs to the top part of the lower stage of the El Castellar Formation (Fig. 1d). Biostratigraphic studies based on charophytes from this lithostratigraphic unit point to an uppermost Hauterivian-basal Barremian age to the El Castellar Formation (Martín-Closas, 1989).

a
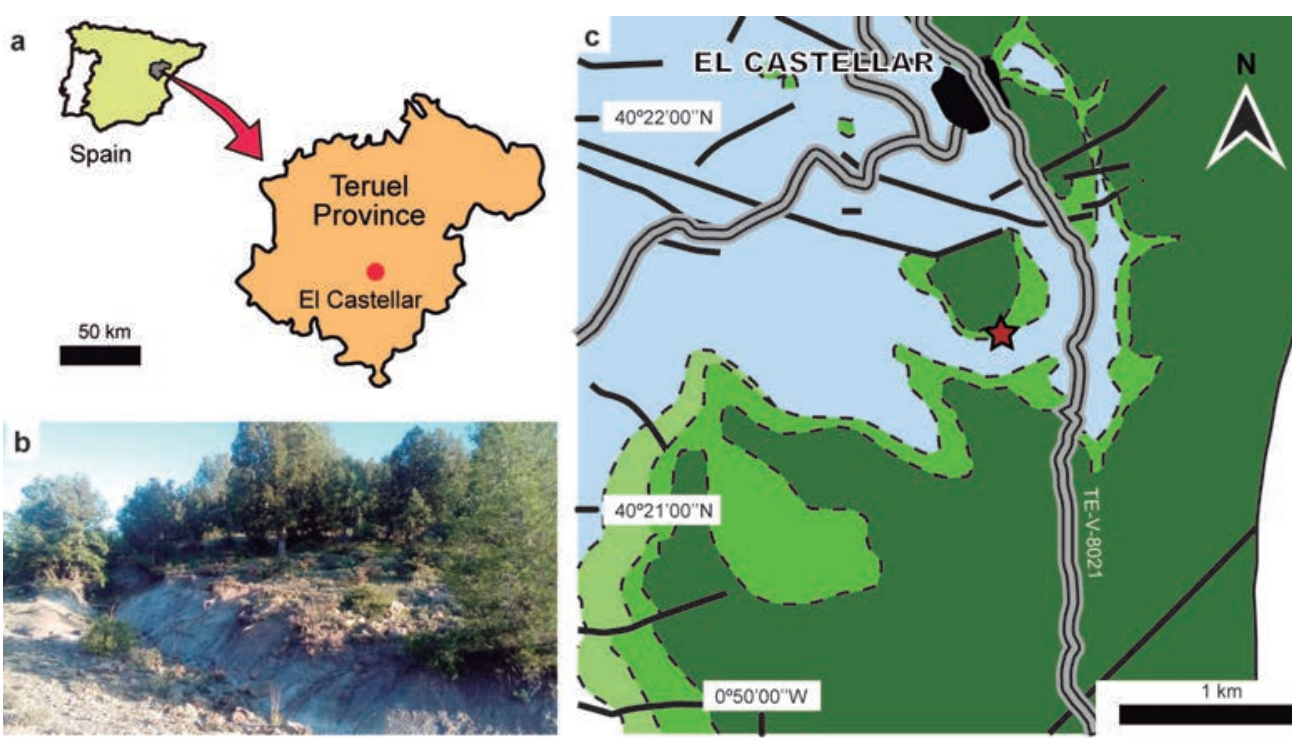

Villar del Arzobispo Fm. (Kimmeridgian -
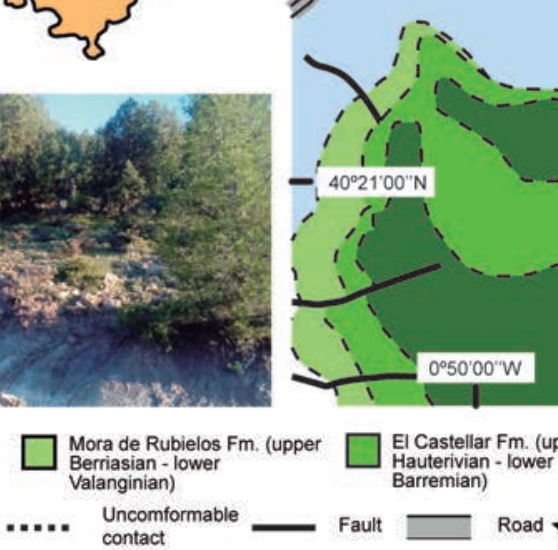


\section{MATERIAL AND METHODS}

\subsection{Material}

According to the size of the fossils studied, the absence of repetition of anatomical elements in fossils of similar size, and some other characteristics, it has been determined that at least three individual large ornithopods, representing two different morphotypes (MOR1 and MOR2), were present in the set of vertebrae from CT-16 and CT-17. Site CT16 yielded fossils corresponding to a huge ornithopod (MOR1), which was mainly represented by platycoelus caudal vertebrae, and fossils belonging to a middle-sized ornithopod (MOR2), which was represented by a longerthan-high platycoelus dorsal and an amphicoelus caudal vertebra (the latter unlike MOR1) (MPA collections; see catalogue numbers in Table 1). The size of the remains of MOR2 is consistent with belonging to the same individual, but such identity is nevertheless uncertain. Appendicular remains were also recognised in CT-16 (e.g., a proximal fragment of a femur which likely belonged to MOR2 because of its size), but they were not considered in this work due to their scarcity. Additionally, a big partial centrum (MAP-803) was also ruled out from this study because it was unclear if it belonged to the dorsal or caudal series. Site CT-17 (Cobos et al., 2012) provided the fossils of an individual similar to and comparable in size with MOR2 of CT-16. This specimen was represented by longerthan-high platycoelus dorsal vertebrae (like MOR2 in CT16), some caudal remains, and appendicular fragments (e.g., a fibular fragment), but only the dorsals were studied here (Table 1) because of the poor preservation of the other fossils. All of these specimens are here considered 'adults' for reasons explored in the 'Discussion'. Note that CPT collection numbers in Cobos et al. (2012) are the same as those designated here as MAP. All these fossils are currently housed in the Museo Aragonés de Paleontología.

Table 1. Fossil vertebrae from CT-16 and CT-17 (housed in the Museo Aragonés de Paleontología, Teruel, Spain).

\begin{tabular}{|c|c|c|c|}
\hline Site & Collection numbers & Element & Assignation \\
\hline \multirow{3}{*}{ CT-16 } & $\begin{array}{l}\text { MAP-793, МAP-794, } \\
\text { MAP-796, MAР-797, } \\
\text { MAP-799, MAP-4548, } \\
\text { MAP-7730, MAP-7731 }\end{array}$ & $\begin{array}{l}\text { Caudal } \\
\text { vertebrae }\end{array}$ & Morphotype 1 \\
\hline & MAP-3907 & $\begin{array}{l}\text { Dorsal } \\
\text { vertebra }\end{array}$ & \multirow{3}{*}{ Morphotype 2} \\
\hline & MAP-3906 & $\begin{array}{l}\text { Caudal } \\
\text { vertebra }\end{array}$ & \\
\hline CT-17 & $\begin{array}{l}\text { MAP-812, MAP-814, } \\
\text { MAP-815, MAP-816, } \\
\text { MAP-929 }\end{array}$ & $\begin{array}{l}\text { Dorsal } \\
\text { vertebrae }\end{array}$ & \\
\hline
\end{tabular}

\subsection{Methods}

Qualitative comparisons with diverse Lower Cretaceous ornithopods were made using the information provided in descriptions of available material in several publications (whose authority is properly cited in the text) and diverse observations made by the senior author (FJV) regarding ornithopod fossils held in several institutions (indicated with the museum numbers). To simplify checking these comparisons, the genus name was only indicated for monospecific species or when the genus was the focus of the discussion. Alternatively, the specific name was only written when a particular species of a multispecific genus was considered. The phylogenetic framework used throughout this work was the evolutionary hypothesis for Iguanodontia proposed by Verdú et al. (2018).

The morphometric study was conducted in the traditional manner by taking linear measurements of the vertebrae using a Vernier calliper with a resolution of 0.05 $\mathrm{mm}$ micrometres. Specifically, six linear measurements were taken (when possible) from a total of 10 vertebral centra in CT-16 and 6 in CT-17 (Table 2).

Then, a dataset was compiled including equivalent measurements in dorsal and caudal centra of other European iguanodontian ornithopods, apart from the measurements obtained in the specimens from CT-16 and CT-17 (Supplementary material). These measurements were collected from publications or were taken directly from their fossils by the authors. European iguanodontians analysed were: Valdosaurus (IWCMS 2013.175 in Barrett, 2016), Eousdryosaurus (SHN(JJS)-170 in Escaso et al., 2014), I. bernissartensis (dorsals of RBINS R352; caudals of RBINS R51 in Norman, 1986), I. cf. galvensis (DS1 in Verdú, 2017), Magnamanus (MNS 2000/132, MNS 2001/122, MNS 2002/95, MNS 2003/69, and MNS 2004/54 in Fuentes et al., 2016), Mantellisaurus (RBINS R57 in Norman, 1986), Morelladon (CMP-MS-03 in Gasulla et al., 2015), and an indeterminate tall-spined iguanodontian (GPIT 1802/1-7 in Pereda-Suberbiola et al., 2011). Other European taxa, the Valanginian styracosternans Barilium and Hypselospinus, were not included in this study due to the fact that their vertebral measurements had not yet been published (Norman, 2011, 2015). The same reasoning is applied for other interesting contemporaneous specimens such as the holotype of 'Delapparentia' (Ruiz-Omeñaca, 2011; formerly Iguanodon sp. in Verdú et al., 2017) or cf. Iguanodon sp. (Torcida Fernández-Baldor et al., 2006 after Gasca et al., 2014). Hence, the resulting table included the length, the height, and the width of the centra of diverse iguanodontians (Supplementary material). Particularly, both height and width were preferably selected from the anterior articular face when available, but often this was not specified by the authors. Additionally, incomplete or estimated linear measurements were ruled out prior to 
Table 2. Measurements (in $\mathrm{mm}$ ) of vertebral specimens listed by site and morphotype. Abbreviations and symbols: V: Type of vertebra (C, Caudal; D, Dorsal); L: Length; W: Width; H: Height; a: anterior; p: posterior; m: minimum; r1: L/((Wa +Wp)/2); r2: L/ $((\mathrm{Ha}+\mathrm{Hp}) / 2) ; \mathrm{r} 3: \mathrm{Ha} / \mathrm{Wa} ; \mathrm{r} 4: \mathrm{Hp} / \mathrm{Wp} ;>$; incomplete; $;$; estimated. Note that specimens are listed in presumably anatomical order.

\begin{tabular}{|c|c|c|c|c|c|c|c|c|c|c|c|}
\hline Museum number & $\mathbf{V}$ & $\mathbf{L}$ & Wa & На & Wp & Нр & $\mathbf{W m}$ & r1 & r2 & r3 & r4 \\
\hline \multicolumn{12}{|l|}{ CT-16 SITE } \\
\hline \multicolumn{12}{|l|}{ Morphotype 1} \\
\hline МАР-797 & $\mathrm{C}$ & 120 & 147.9 & $>113.4$ & 144.9 & $>124.4$ & - & 0.82 & - & - & - \\
\hline МАР-794 & $\mathrm{C}$ & 120.1 & 139.6 & $>105.9$ & 129.3 & 121.3 & 106.5 & 0.89 & $0.99_{p}$ & - & 0.94 \\
\hline МАР-796 & $\mathrm{C}$ & 107.2 & $>114.3$ & $>109.4$ & 125.3 & 121.4 & - & $0.86_{p}$ & $0.88_{p}$ & - & 0.97 \\
\hline МАР-793 & $\mathrm{C}$ & 97 & 107 & $>116.2$ & 104.5 & $>111.4$ & $\sim 78.8$ & 0.92 & $0.85_{p}$ & - & - \\
\hline MAP-7731 & $\mathrm{C}$ & 89.8 & 103.1 & $>104.1$ & 98.5 & 105 & $\sim 71$ & 0.89 & $0.86_{p}$ & - & 1.07 \\
\hline MAP-7730 & $\mathrm{C}$ & 93.7 & 80.2 & 90.2 & 84.2 & $\sim 82.9$ & - & 1.14 & $1.04_{\mathrm{a}}$ & 1.13 & - \\
\hline МАP-4548 & $\mathrm{C}$ & 100.8 & 87.6 & 86.1 & 90 & 79.2 & 74.3 & 1.14 & 1.22 & 0.98 & 0.88 \\
\hline МАР-799 & $\mathrm{C}$ & 63.1 & $>46.6$ & 46.5 & $>41.1$ & $>42.4$ & 27.7 & - & $1.36_{\mathrm{a}}$ & - & - \\
\hline \multicolumn{12}{|l|}{ Morphotype 2} \\
\hline MAP-3907 & $\mathrm{D}$ & 85 & $\sim 54.6$ & 66.9 & 53.7 & 65.6 & $>33.3$ & - & 1.28 & - & 1.22 \\
\hline МАР-3906 & $\mathrm{C}$ & 76.6 & 64 & 67 & 60.6 & 62.8 & 44 & 1.23 & 1.18 & 1.05 & 1.04 \\
\hline \multicolumn{12}{|l|}{ CT-17 SITE } \\
\hline \multicolumn{12}{|l|}{ Morphotype 2} \\
\hline МАР-929 & $\mathrm{D}$ & 81.6 & - & - & - & - & - & - & - & - & - \\
\hline МАР-812 & $\mathrm{D}$ & - & - & - & 60.4 & 76 & & - & - & - & 1.26 \\
\hline MAP-816 & $\mathrm{D}$ & 90.8 & 54.9 & 71.4 & 61.7 & 75 & 39.6 & 1.56 & 1.24 & 1.30 & 1.22 \\
\hline MAP-814 & $\mathrm{D}$ & 85.6 & 61.3 & 72 & 59.6 & 71.2 & 40.2 & 1.42 & 1.2 & 1.17 & 1.19 \\
\hline MAP-815 & $\mathrm{D}$ & 80.8 & 64.6 & 80.7 & 64.2 & 74.4 & 47.3 & 1.25 & 1.04 & 1.25 & 1.16 \\
\hline МАР-930 & $\mathrm{D}$ & $>63.5$ & - & - & - & - & - & - & - & - & - \\
\hline
\end{tabular}

the analysis. Posteriorly, this dataset was analysed by principal components analysis (PCA) using free PAST v.3.0 software (Hammer et al., 2001) to determine which European taxa were more morphologically related to fossils from CT-16 and CT-17. PCA is a multivariate exploratory technique that transforms original variables into a new uncorrelated set of variables called principal components (PC) (Blanco et al., 2015). In fact, these new variables are linear combinations of the originals (Hammer, 2018). In this way, PCA allows researchers to quantify the variance between species as well as specimens (Fearon \& Varricchio, 2015). Two different PC analyses were performed for each dorsal and caudal centra: one analysed raw data without applying any transformation, and the other removed the size component from the dataset to minimize its impact on the variance (Fearon \& Varricchio, 2015). In the second analysis, measurements were transformed with the 'Remove size from distances' tool, applying the option 'Allometric vs. standard' prior to PCA. For both analyses, PCA was done using a variancecovariance matrix because all data had the same units (millimetres) (Hammer, 2018). Moreover, options for groups were set at 'Disregard'. Additionally, estimation of missing values was made through the recommended option of 'Iterative imputation' (Hammer, 2018). Finally, 1000 bootstrapping replicates were performed for each analysis.

As result, the output data of the PCA included: a distribution plot of the calculated PC scores of each dorsal/caudal vertebra for each taxa with respect to the two principal components obtained, eigenvalues that provided a measure of the variance accounted for by the corresponding eigenvectors (components), percentage of variance according to the eigenvalues for each component, and PCA loading scores which showed the degree that the original variables entered into the different components (Hammer, 2018). Components were considered significant if eigenvalues were over 1 (Fearon \& Varricchio, 2015). PCA loading scores were obtained with the 'correlation' option selected, which provided the R-squared Pearson index for correlation between the original variable and the PC scores (Hammer, 2018). 


\section{SYSTEMATIC PALAEONTOLOGY}

\author{
Superorder DINOSAURIA Owen, 1842 \\ Order ORNITHISCHIA Seeley, 1887 (sensu Sereno, \\ 2005)
}

Suborder ORNITHOPODA Marsh, 1882

Clade IGUANODONTIA Dollo, 1888 (sensu Sereno, 1998)

Clade EUIGUANODONTIA Coria \& Salgado, 1996 (sensu Verdú et al., 2018)

Clade DRYOMORPHA Sereno, 1986 (sensu Sereno, 2005)

Clade ANKYLOPOLLEXIA Sereno, 1986 (sensu Sereno, 2005)

Clade STYRACOSTERNA Sereno, 1986

Styracosterna indet. 1 (MOR1)

Material. Eight anterior, middle, and posterior caudal vertebral centra (MAP-793, MAP-794, MAP-796, MAP797, MAP-799, MAP-4548, MAP-7730, and MAP-7731) from CT-16 were analysed (Figs 2-3).

Description. Caudal vertebrae. The most anterior caudal centra, such as MAP-797 (Fig. 2a) and MAP-794 (Fig. 2b), have a block-like shape with broad (i.e., wider than high) subquadrangular anterior and posterior articular faces. However, articular faces become progressively and proportionally higher towards the posterior vertebrae of this part of the tail, so height and width are similar in MAP-796 (Fig. 2c), MAP-793 (Fig. 2d), and MAP-7731 (Fig. 3a). Even though MAP-797 can be described as amphiplatyan (slightly platycoelous), the articular surfaces are fully platycoelous in the successive anterior caudal centra (MAP-794, MAP-796, MAP-793, and MAP-7731). In lateral view, the first anterior caudal centra are as long as they are high (MAP-797 [Fig. 2a], MAP-794 [Fig. 2b], and MAP-796 [Fig. 2c]), but they become higher than long toward the middle region of the tail (MAP-793 [Fig. 2d] and MAP-7731 [Fig. 3a]). Although the ventral surface is poorly preserved in all examples, chevron facets seem to be small (or absent) in MAP-797, similar to the structure observed in the first caudal vertebra of I. bernissartensis (Norman, 1980). In lateral view, the ventral margin descends from the anterior articular surface to the posterior because of the drop of the tail from the sacrum (Norman, 1980). The neurocentral suture is closed in all examples, and part of the transverse process is still appreciable laterally in some centra (e.g., MAP-793 [Fig. 2d]).

Moving backwards along the caudal series, the middle caudal vertebrae are recognised for the loss of the transverse processes in the neural arch. Unfortunately, MAP-7730 (Fig. 3b) and MAP-4548 (Fig. 3c) are the only middle centra preserved in CT-16. These are rectangular and longer than high in lateral view. Particularly, articular faces adopt a hexagonal outline in MAP-4548 (Fig. 3c) as consequence of a ridge, which extends longitudinally on the lateral side of the centrum. This is characteristic of Iguanodontia (Norman, 2004). MAP7730 is platycoelous, but MAP-4548, posterior to the former, is slightly amphicoelous. Additionally, chevron facets are more modest than in anterior caudal vertebrae, with the posterior ones being the largest. A ventral sulcus runs along the ventral surface in both MAP-7730 (Fig. 3b) and MAP-4548 (Fig. 3c). As in the anterior caudal vertebrae, the neurocentral suture is closed in the middle caudal vertebrae.

Finally, the most distal region of the tail is only represented by MAP-799 (Fig. 3d), a small and amphiplatyan reel-like centrum that is highly compressed between both articular faces. In lateral view, this centrum has a markedly arched ventral surface.

\section{Styracosterna indet. 2 (MOR2)}

Material. One dorsal vertebra (MAP-3907) and one caudal vertebra (MAP-3906) from CT-16 (Fig. 4), along with several dorsal vertebrae (MAP-812, MAP-814, MAP815, MAP-816, and MAP-929) and a caudal vertebra (MAP-930) from CT-17 were analysed (Fig. 5).

Description. Fossils from CT-17 have already been described in detail by Cobos et al. (2012), so only a general description of them is provided in the following paragraph.

Dorsal vertebrae. MAP-3907 from CT-16 (Fig. 4a) is tentatively identified as part of the anterior-to-middle region of the dorsal series, whereas MAP-929 (Fig. 5a), MAP-816 (Fig. 5b), MAP-814 (Fig. 5c), and MAP-815 (Fig. 5d) are likely from the middle-to-posterior region. MAP-812 represents part of a vertebral centrum (possibly its posterior articular face), and its anatomical position is uncertain. Overall, the centra are spool-like, longer than high, and moderately compressed between the articular faces. Their articular surfaces are platycoelous and elliptical (higher than wide), with no everted margins. Additionally, they have a sharp longitudinal keel extending along the ventral side of the centra (e.g., Fig. 5c). The sinuous neurocentral suture is closed in all the vertebrae studied, except for MAP-816, whose suture is partially closed. Finally, the unique changes noticed along the dorsal series are that the centra become slightly anteroposteriorly compressed, more robust, and acquire a more modest ventral keel (MAP-815, Fig. 5d) toward the sacrum.

Caudal vertebrae. MAP-3906 (Fig. 4b) is the bestpreserved caudal vertebrae for MOR2 (MAP-930 from CT-17 is highly eroded). It can be identified as a member 


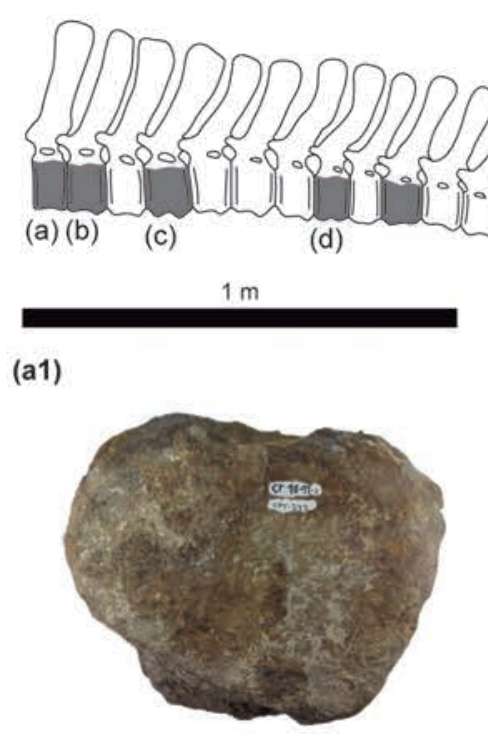

(b1)

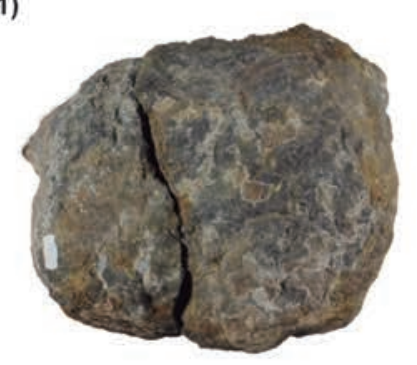

(c1)

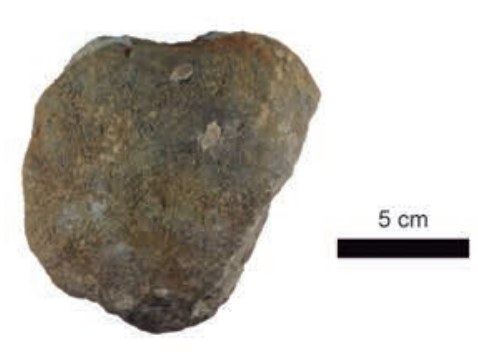

(a2)

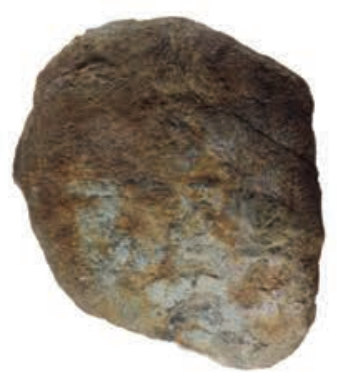

(b2)

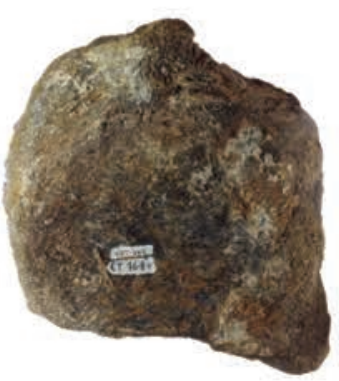

(c2)

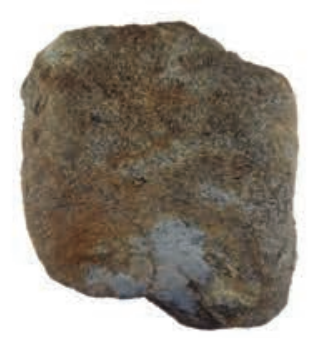

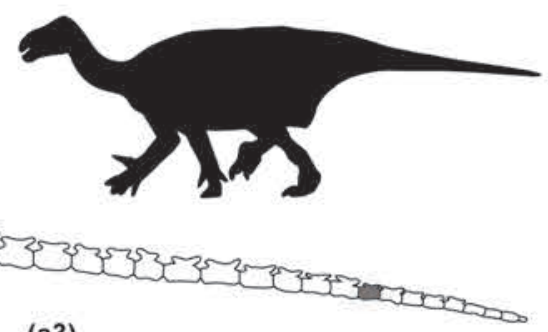

(a3)

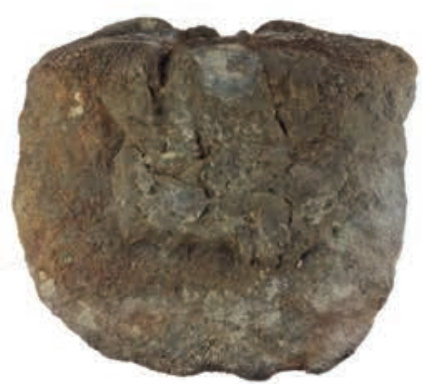

(b3)

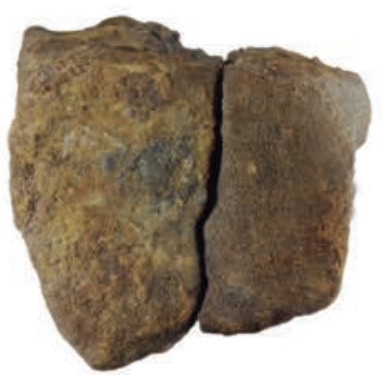

(c3)

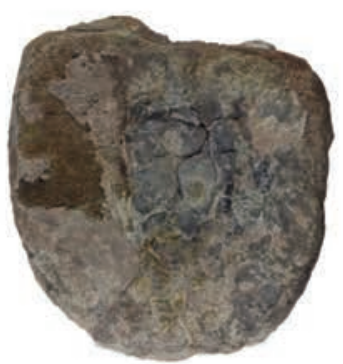

(d4)

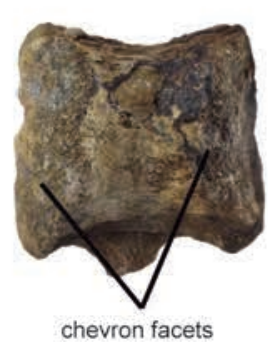

Figure 2. Caudal vertebrae of Styracosterna indet. 1 (MOR1) from CT-16. At top: the estimated position of the vertebrae along the caudal series (in grey). Both the outline of the caudal series and the ornithopod shade have been redrawn and modified from Iguanodon bernissartensis drawing in Paul (2008; Fig. 1c). a) Anterior caudal centrum MAP-797: (a1) anterior view; (a2) left lateral view; (a3) posterior view. b) Anterior caudal centrum MAP-794: (b1) anterior view; (b2) left lateral view; (b3) posterior view. c) Anterior caudal centrum MAP-796: (c1) anterior view; (c2) right lateral view (reversed); (c3) posterior view. d) Anterior caudal centrum MAP-793: (d1) anterior view; (d2) right lateral view (reversed); (d3) posterior view; (d4) ventral view. 

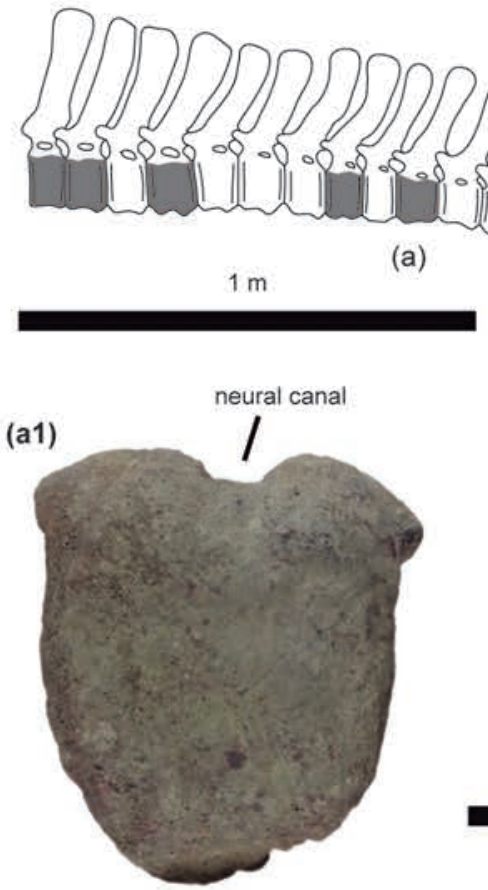

(b1)

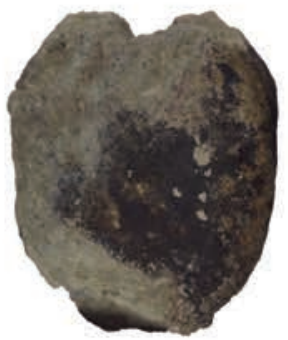

(c1)

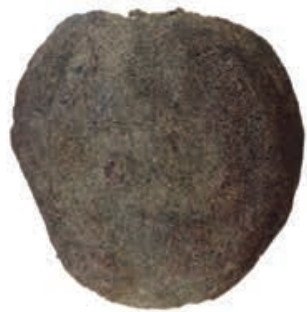

(d1)

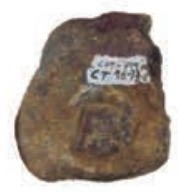

(b)

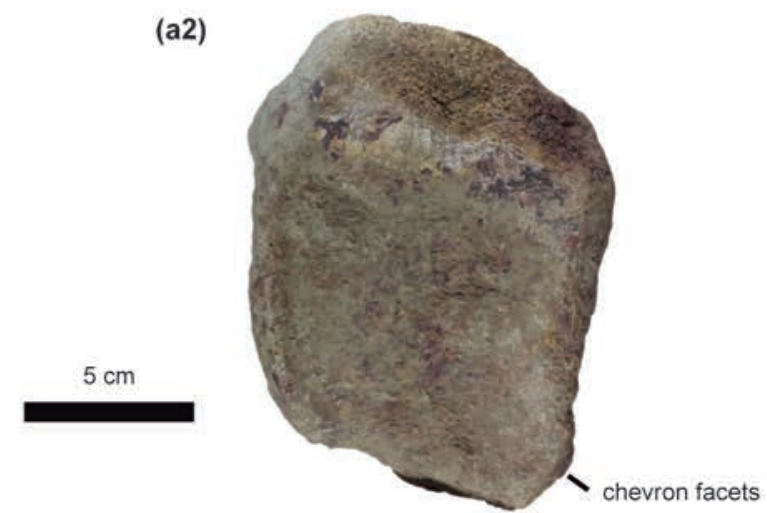

(b2)

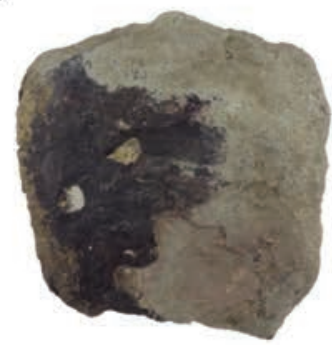

(b3)

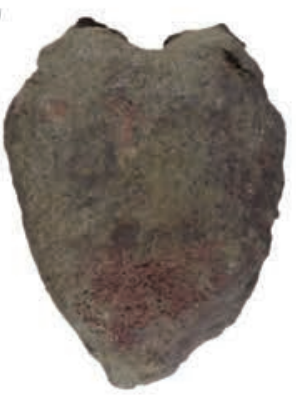

(c2)

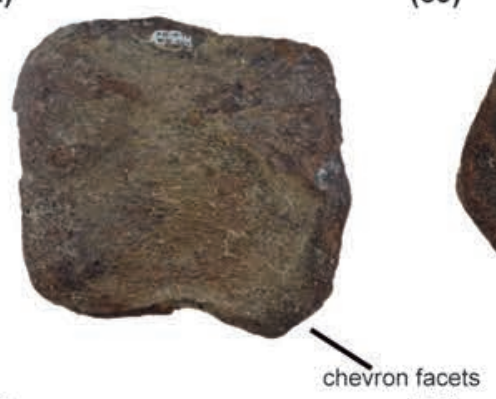

(d2)
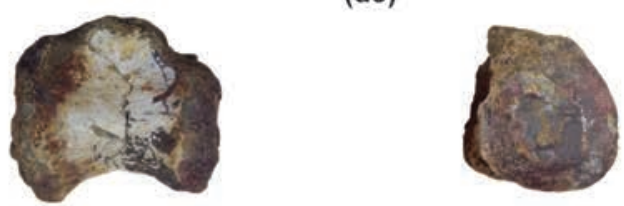

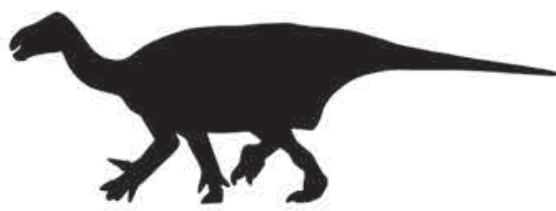

(c)

(d)

(a3)

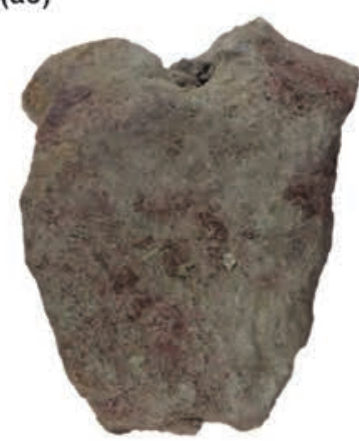

(b4)

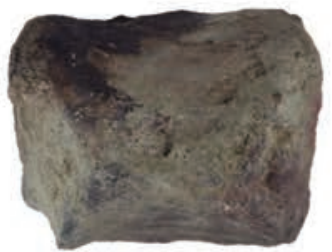

(c4)

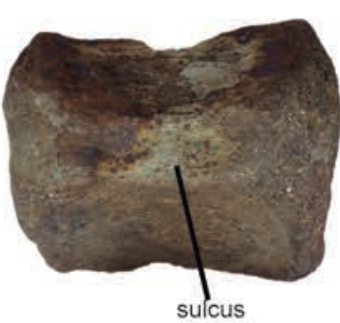

(d4)

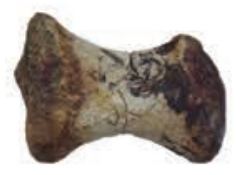

Figure 3. Caudal vertebrae of Styracosterna indet. 1 (MOR1) from CT-16. At top: the estimated position of the vertebrae along the caudal series (in grey). Both the outline of the caudal series and the ornithopod shade have been redrawn and modified from Iguanodon bernissartensis drawing in Paul (2008; Fig. 1C). a) Anterior caudal centrum MAP-7731: (a1) anterior view; (a2) left lateral view; (a3) posterior view. b) Middle caudal centrum MAP-7730: (b1) anterior view; (b2) left lateral view; (b3) posterior view; (b4) ventral view. c) Middle caudal centrum MAP-4548: (c1) anterior view; (c2) right lateral view (reversed); (c3) posterior view; (c4) ventral view. d) Posterior caudal centrum MAP-799: (d1) anterior view; (d2) right lateral view (reversed); (d3) posterior view; (d4) ventral view. 
of the anterior series (likely one of the last in this region) since it still preserves the base of the transverse processes. MAP-3906 is a bit larger than high, slightly amphicoelous (unlike platycoelus anterior caudal vertebrae of MOR1), and has inverted triangular articular faces. Additionally, it bears chevron facets both anteriorly and posteriorly on its ventral surface. The neurocentral suture is closed in this specimen.

\section{MULTIVARIATE ANALYSIS RESULTS}

It should be noted that specimens included in the analysis do not necessarily represent the entire dorsal or caudal series of a particular taxon, so their morphospaces are not completely represented in several cases. Additionally, it should be considered when interpreting the results that some vertebral centra exhibit similar proportions in different regions of dorsal/caudal series for different taxa. For instance, the length/height ratio in the distal caudal vertebrae of the styracosternan I. bernissartensis (1.82 in the $43^{\text {rd }}$ caudal vertebra of RBINS R51 [Norman, 1986]) is similar to that of the middle caudal vertebrae of the dryosaurid Valdosaurus (1.81 in the $20^{\text {th }}$ caudal vertebra of IWCMS 2013.175 [Barrett, 2016]). This could explain some of the phylogenetically inconsistent overlapping observed among different taxa in the results (Fig. 6).

Caudal vertebrae. When the size effect is not removed from the dataset, the first component (PC1) contributes to the variance by $94.8 \%$, whereas the second component
(PC2) contributes by only 4.5\%. Eigenvalues of both components are significant (Table 3). PCA loading scores indicate that correlation with the length, the height, and the width is high with PC1, but not with PC2 (Table 3). The analysis of caudal centra does not resolve the separated morphospace in shape among the different European iguanodontians (Fig. 6a), except for the dryosaurid Eousdryosaurus, which is characterized for having larger than high anterior caudal vertebrae (Escaso et al., 2014). MOR1 from CT-16 occupies an area, which overlaps significantly with that of Magnamanus and $I$. bernissartensis, and to a lesser extent with that of Mantellisaurus. Additionally, the caudal centrum of MOR2 from CT-16 falls within the morphospace of MOR1, Mantellisaurus, and Magnamanus. When size effect is removed from the dataset (Fig. 6b), the differences among the caudal series of European iguanodontians become even more attenuated so that the majority are agglomerated around central scores of both components with an extensive overlap of all of them, including MOR1 and MOR2. As in the previous analysis, the unique iguanodontian, which occupies an (almost) exclusive area in the negative scores of the first component, is Eousdryosaurus. In this analysis, PC1 explains $88 \%$ of the variance whereas PC2 explains 12\%. Loading scores indicate that height and width correlates with $\mathrm{PC} 1$, especially the latter, and that height partially correlates with PC2 (Table 3). Note that length has been equalled in every specimen when the size component is removed from the dataset so that it does not produce variation.

Table 3. Output data of the PCA. Abbreviations: L: Length; H: Height; PC: Principal component; W: Width.

\begin{tabular}{|c|c|c|c|c|c|c|c|}
\hline \multirow{2}{*}{ PC } & \multirow{2}{*}{ Eigenvalue } & \multirow{2}{*}{$\%$ variance } & \multicolumn{2}{|c|}{ Confidence interval } & \multicolumn{3}{|c|}{ Correlation } \\
\hline & & & $2.5 \%$ & $97.5 \%$ & $\mathrm{~L}$ & $\mathrm{H}$ & $\mathrm{W}$ \\
\hline \multicolumn{8}{|c|}{ Caudal - including size } \\
\hline 1 & 2894.84 & 94.779 & 92.545 & 96.652 & 0.91396 & 0.99336 & 0.98468 \\
\hline 2 & 137.218 & 4.4926 & 2.7536 & 6.709 & 0.40462 & -0.060178 & -0.14848 \\
\hline 3 & 22.2537 & 0.7286 & 0.27864 & 1.2545 & 0.030898 & -0.098078 & 0.091442 \\
\hline \multicolumn{8}{|c|}{ Caudal - excluding size } \\
\hline 1 & 1043.49 & 88.006 & 81.458 & 92.907 & 0 & 0.80212 & 0.98365 \\
\hline 2 & 142.217 & 11.994 & 7.0931 & 18.542 & 0 & 0.59717 & -0.18007 \\
\hline 3 & 0 & 0 & 0 & 0 & 0 & 0 & 0 \\
\hline \multicolumn{8}{|c|}{ Dorsal - including size } \\
\hline 1 & 2101.56 & 88.539 & 82.908 & 92.937 & 0.79232 & 0.98004 & 0.94765 \\
\hline 2 & 203.292 & 8.5647 & 5.0305 & 13.118 & 0.55156 & 0.10225 & -0.2967 \\
\hline 3 & 68.735 & 2.8958 & 1.4793 & 4.4882 & 0.2608 & -0.1705 & 0.118 \\
\hline \multicolumn{8}{|c|}{ Dorsal - excluding size } \\
\hline 1 & 1048.77 & 89.407 & $6.47 \times 10^{-28}$ & 92.917 & 0 & 0.94977 & 0.94102 \\
\hline 2 & 124.255 & 10.593 & 6.2708 & 17.778 & 0 & -0.31296 & 0.33835 \\
\hline 3 & $1.01 \times 10^{-21}$ & $8.58 \times 10^{-24}$ & $6.53 \times 10^{-28}$ & 93.37 & 0 & 0 & $-9.27 \times 10^{-45}$ \\
\hline
\end{tabular}




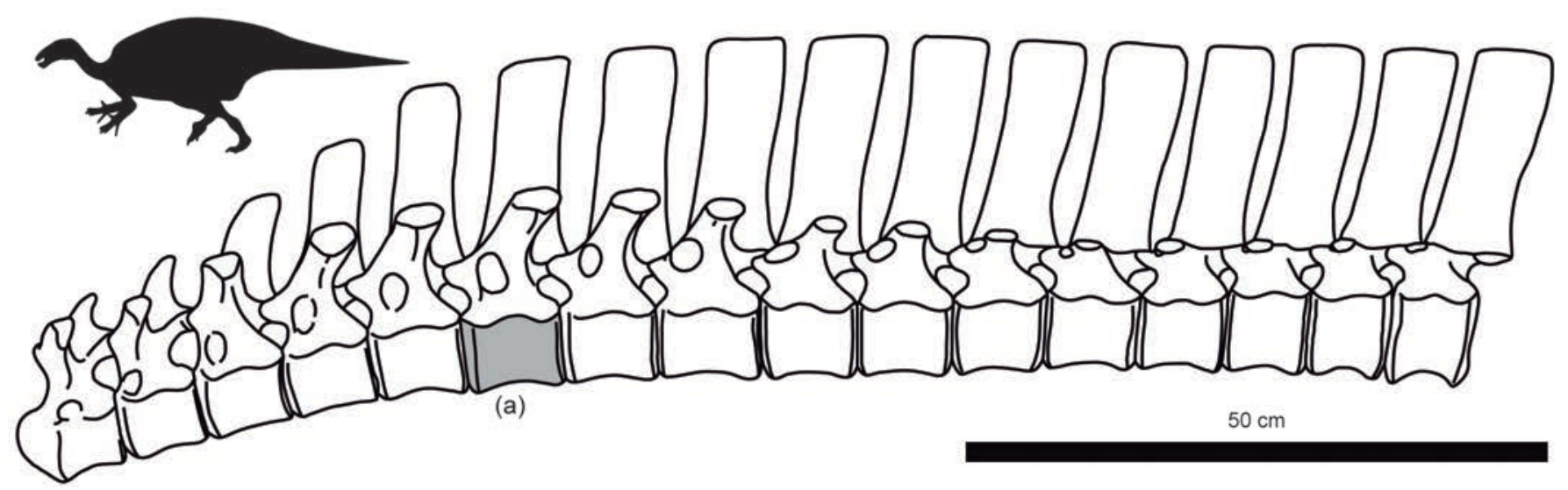

(a1)

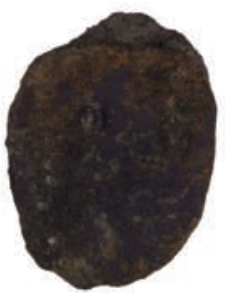

(b1)

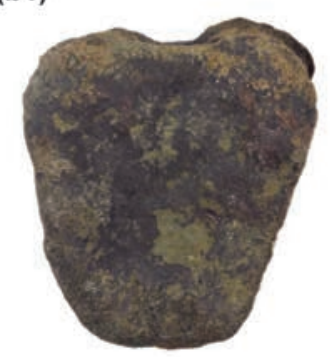

(a2)

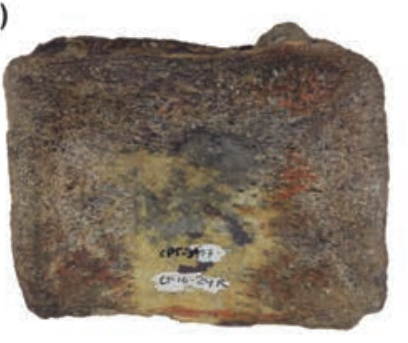

(b2)

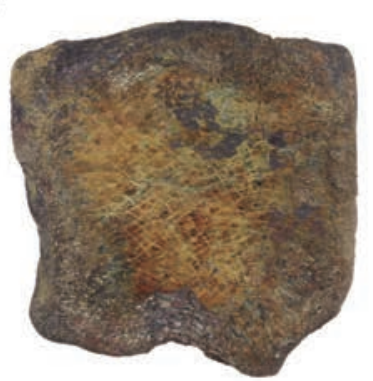

(a3)

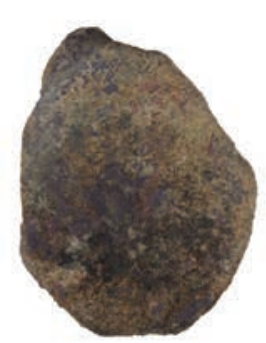

(b3)

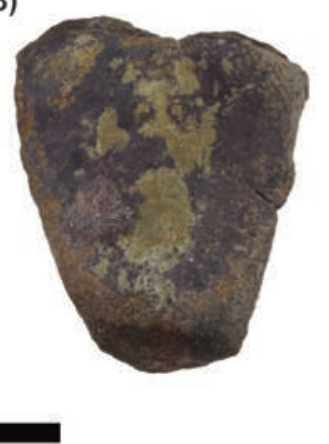

(a4)

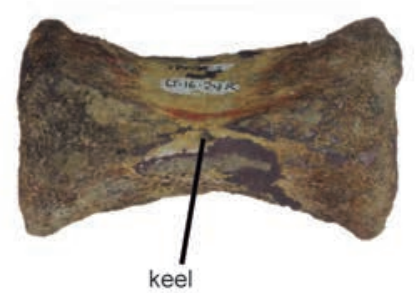

(b4)

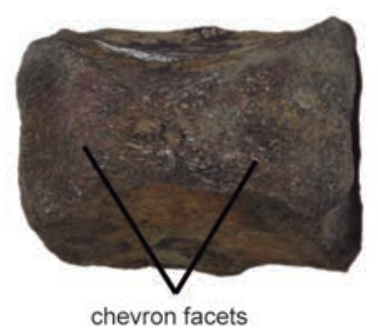

Figure 4. Dorsal and caudal vertebrae of Styracosterna indet. 2 (MOR2) from CT-16. At top: the estimated position of the vertebrae along the dorsal series (in grey). The outline of the dorsal series has been redrawn from Norman (1986; Figs 29B and 31B). The ornithopod profile has been modified from Mantellisaurus atherfieldensis drawing in Paul (2008; Fig. 1C). a) Dorsal centrum MAP-3907: (a1) anterior view; (a2) left lateral view; (a3) posterior view; (a4) ventral view. b) Anterior caudal centrum MAP-3906: (b1) anterior view; (b2) left lateral view; (b3) posterior view; (b4) ventral view.

Dorsal vertebrae. When size effect is not removed from the dataset, PC1 explains the $88.4 \%$ variance, while PC2 only contributes to it by $8.6 \%$. According to loading correlation values (Table 3 ), the length, height, and width contribute highly to the variation of PC1. If the resulting plot of the PCA is observed (Fig. 6c), two areas of distribution are clearly differentiated along the morphospace. Dorsal centra of MOR2 from CT-16 and CT-17 are placed into the negative scores of PC2 along with Valdosaurus, Morelladon, Mantellisaurus, and the indeterminate tall-spined iguanodontian (GPIT 1802/1-7). However, dorsal centra of Magnamanus, I. bernissartensis, and $I$. cf. galvensis are distributed over the positive scores of PC2. Particularly, the area occupied by the dorsal centra from CT-17 widely overlaps with Morelladon, whereas the unique vertebra from CT-16 does not fall in the morphospace of any iguanodontian. In contrast, distinctions among dorsal vertebrae of different iguanodontians are not as clear as in the previous analysis when size effect is removed from the dataset (Fig. 6d). Not only the CT-16 morphospace overlaps with that of Morelladon, it also overlaps broadly with those of Valdosaurus, Magnamanus, I. bernissartensis, or I. cf. galvensis. In this case, PC1 explains $89.4 \%$ of the variation, while PC2 only explains $10.6 \%$. The two variables of height and width widely explain PC1 (Table 3). 


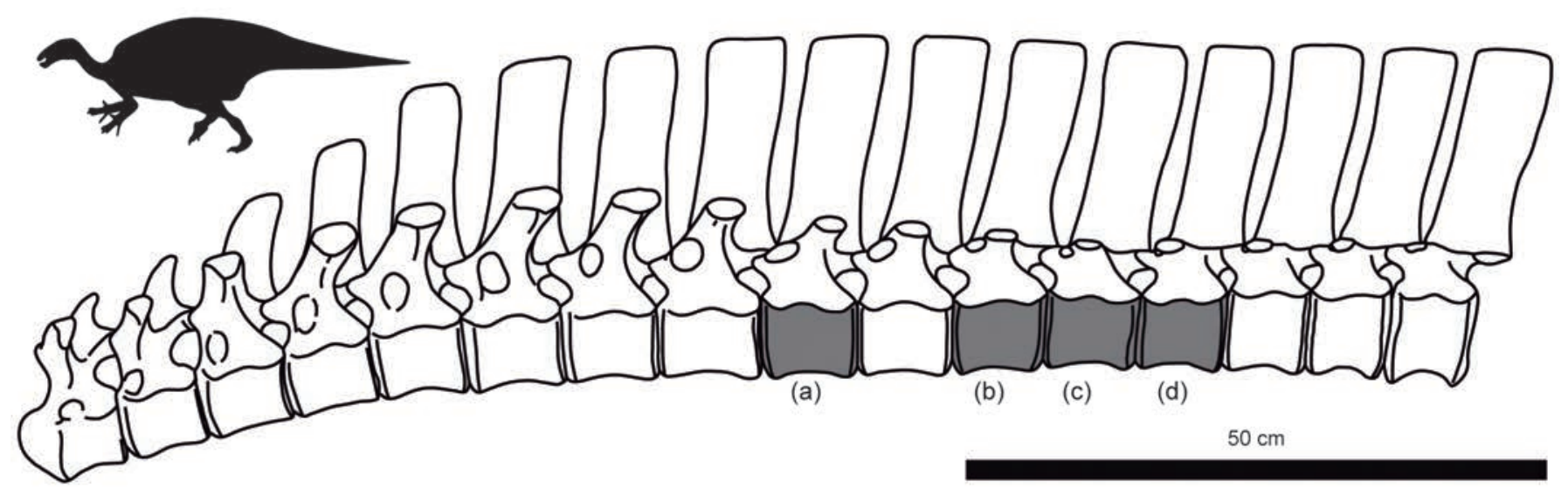

(a1)

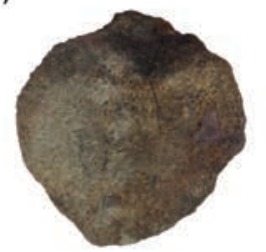

(b1)

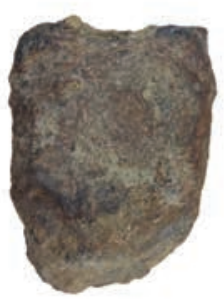

(c1)

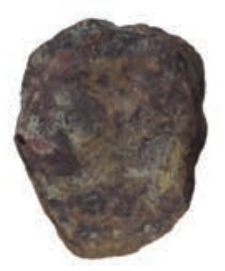

(d1)

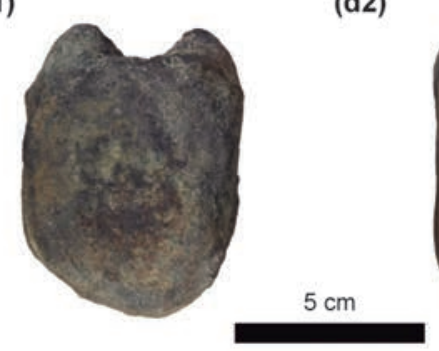

(a2)

(b2)

(c2)

(d2)
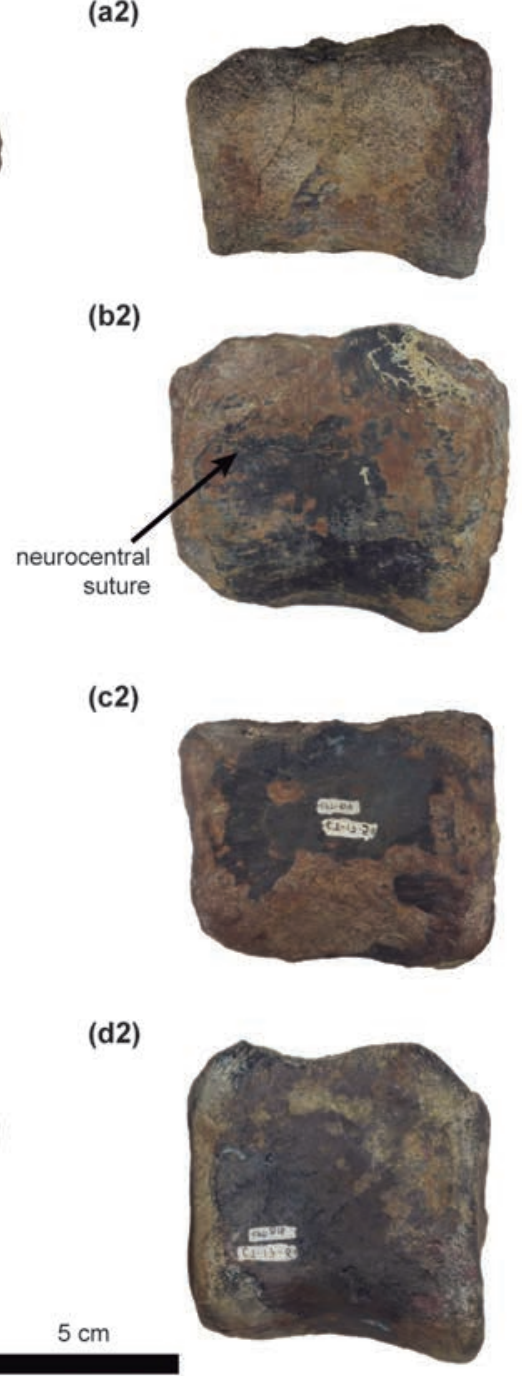

(a3)

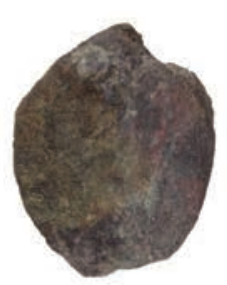

(b3)

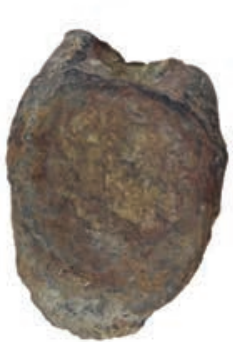

(c3)

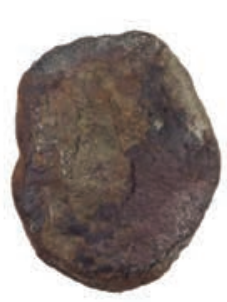

(d3)

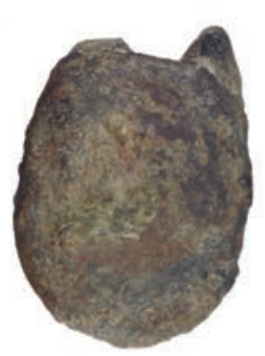

(a4)

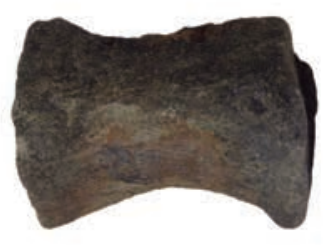

(b4)

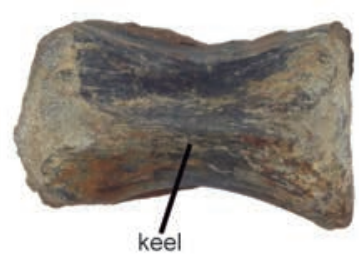

(c4)

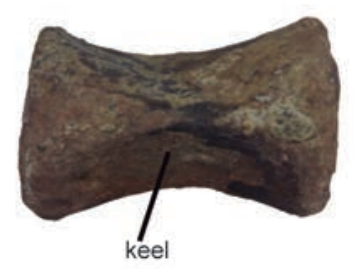

(d4)

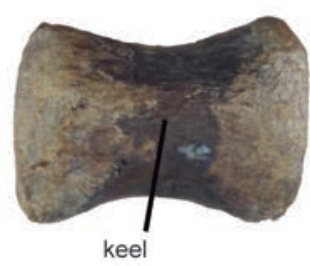

Figure 5. Dorsal vertebrae of Styracosterna indet. 2 (MOR2) from CT-17. At top: the estimated position of the vertebrae along the dorsal series (in grey). The outline of the dorsal series has been redrawn from Norman (1986; Figs 29b and 31b). The ornithopod profile has been modified from Mantellisaurus atherfieldensis drawing in Paul (2008; Fig. 1c). a) Dorsal centrum MAP-929: (a1) anterior view; (a2) right lateral view (reversed); (a3) posterior view; (a4) ventral view. b) Dorsal centrum MAP-816: (b1) anterior view; (b2) left lateral view; (b3) posterior view; (b4) ventral view. c) Dorsal centrum MAP-814: (c1) anterior view; (c2) right lateral view (reversed); (c3) posterior view; (c4) ventral view. d) Dorsal centrum MAP-815: (d1) anterior view; (d2) right lateral view (reversed); (d3) posterior view; (d4) ventral view. 

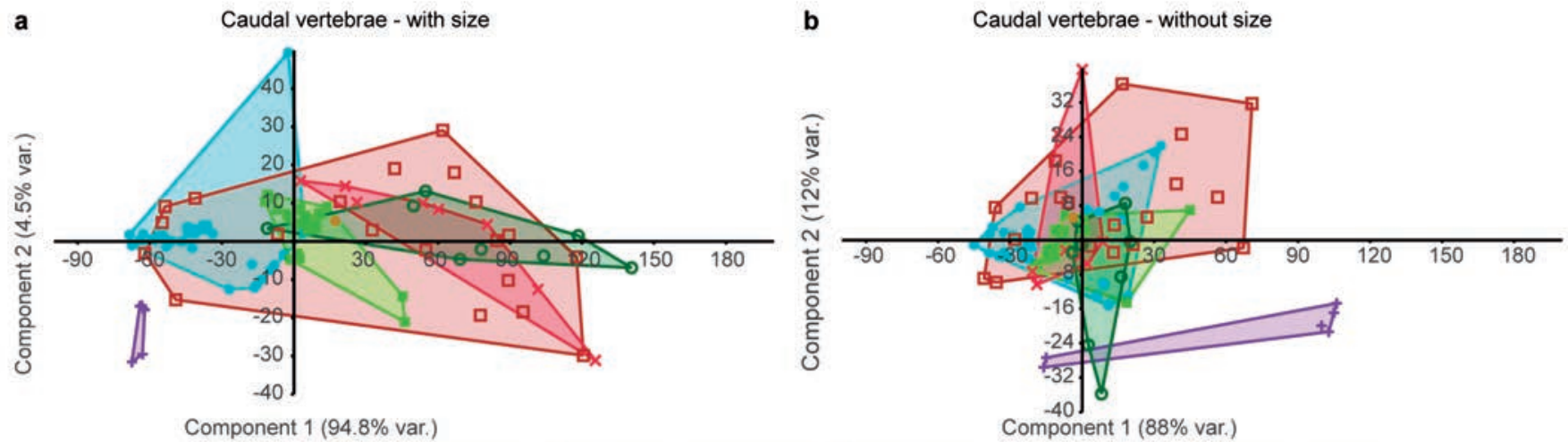

+Eousdryosaurus nanohallucis -Valdosaurus canaliculatus = Mantellisaurus atherfieldensis $\square$ Magnamanus soriaensis xlguanodon bernissartensis o MOR1 (CT-16) •MOR2 (CT-16)

C

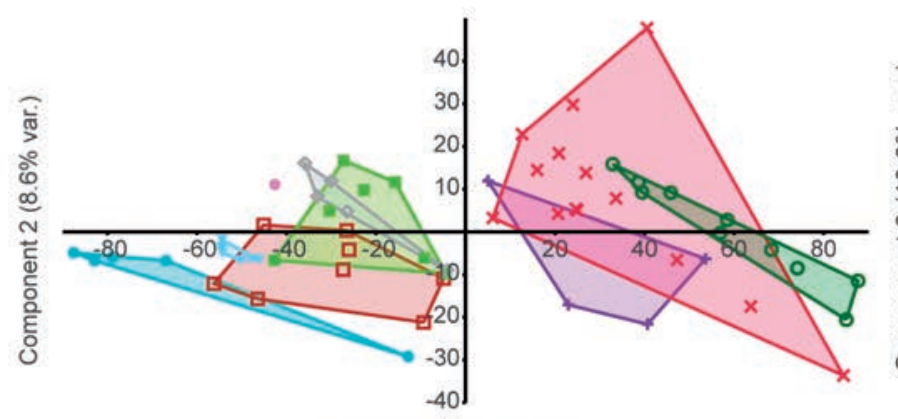

Component $1(88.4 \%$ var.) d Dorsal vertebrae - without size

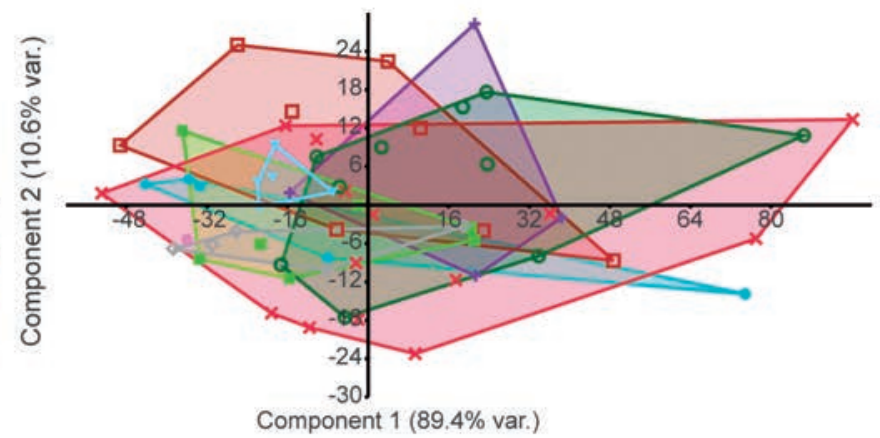

- Valdosaurus canaliculatus =Morelladon beltrani 口Mantellisaurus atherfieldensis +Magnamanus soriaensis x Iguanodon bernissartensis olguanodon cf. galvensis * GPIT 1802/1-7 • MOR2 (CT-16) • MOR2 (CT-17)

Figure 6. PCA plots of lineal measurements from iguanodontian dorsal and caudal vertebral centra, including those from CT-16 and CT-17. a) Analysis for caudal centra including size. b) Analysis for caudal central excluding size. c) Analysis for dorsal centra including size. d) Analysis for dorsal central excluding size.

\section{DISCUSSION}

The features of MOR1 and MOR2 are similar to those of ornithopods described in Europe (as will be discussed in the following paragraphs). In fact, MOR1 and MOR2 are strongly different from other European and Barremian dinosaurs, despite their fragmentary nature. These Barremian faunas are composed of brachiosaurids and rebbachisaurids (among the sauropods), ceratosaurs, baryonychine spinosaurids, carcharodontosaurids, ornithomimosaurs, other small coelurosaurs (among the non-avian theropods), and ankylosaurs (among the thyreophorans), apart from small and large ornithopods (Pereda-Suberbiola et al., 2012; Alcalá et al., 2018 and references therein). Iberian and Barremian sauropods resembling either the upper Hauterivian-lower Barremian Soriatitan or the Barremian-Aptian Tastavinsaurus have bigger adult vertebrae, pleurocoelic dorsals, and more rounded articular faces in the proximal and distal caudals (Canudo et al., 2008; Royo-Torres, 2009; Royo-Torres et al., 2017) than MOR1 and MOR2. Theropods similar in size to MOR1 and MOR2, such as either the upper Barremian carcharodontosaurid Concavenator from the Iberian Peninsula or the baryonychine spinosaurid Baryonyx, exhibit extremely compressed dorsal and caudal centra between their articular faces (Charig \& Milner, 1997; Ortega et al., 2010; Cuesta et al., 2019), strikingly different to the condition observed in MOR1 and MOR2. Finally, thyreophorans such as the Barremian ankylosaur Polacanthus, whose remains have been identified in the Iberian Peninsula (e.g., Gasulla et al., 2011), have very different wider-than-high dorsal vertebrae which are excavated dorsally forming a $\mathrm{V}$-shape pit, anterior caudals with hearth-shaped articular faces, and middle caudal vertebrae with rounded articular faces and transverse processes (Hulke, 1881; Pereda-Suberbiola, 1994), unlike MOR1 and MOR2.

As mentioned above, the group of dinosaurs with which MOR1 and MOR2 share further characters are the ornithopods. Unfortunately, synapomorphic characters of 
Ornithopoda, which are primarily restricted to the cranial and appendicular skeleton (Norman, 2004; Butler et al., 2008; Boyd, 2015), are not identified in MOR1 and MOR2. However, attending to the differences stated above with other contemporaneous dinosaurs, the following combination of characters suggests an affinity with Ornithopoda: the dorsal centra of MOR2 is moderately compressed between the narrow articular faces, and, according to Knoll (2009), without pleurocoeli and with a sinuous neurocentral suture; and caudal centra of MOR1 and MOR2 are slightly compressed between the articular faces, which range from sub-quadrangular to triangular, and without transverse processes in the middle ones. Four groups of ornithopods can be distinguished in the Lower Cretaceous of the Iberian Peninsula: small basal ornithopods related to the English taxon Hypsilophodon (e.g., Sanz et al., 1983; Ruiz-Omeñaca et al., 2012), small basal iguanodontians related to the Upper Cretaceous rhabdodontids (Dieudonné et al., 2016), dryosaurids related to the English taxon Valdosaurus (e.g., Galton, 2009), and diverse large non-hadrosaurid styracosternans (e.g., Gasca et al., 2014; Gasulla et al., 2014, 2015; Verdú et al., 2015; Fuentes et al., 2016), the latter being the group most frequently found in the fossil record. It should be noted that some Lower Cretaceous Iberian fossils identified as basal ornithopods, indeed, might be basal ornithischians (Pereda-Suberbiola et al., 2012). In this context of ornithopod diversity, the vertebral centra of both MOR1 and MOR2 are much too big to belong to mature specimens of basal ornithopods such as Hypsilophodon (Galton, 1974), basal rhabdodontomorphans (Dieudonné et al., 2016) or dryosaurids such as Valdosaurus (Barrett, 2016). Additionally, dorsal centra in Hypsilophodon and basal rhabdodontomorphans exhibit length/height ratio (L/H) (Hypsilophodon: L/H: > 1.8 [Cobos et al., 2012]; basal rhabdodontomorphans: MDS. VG 66 and 69: 1.46-1.76 [Dieudonné et al., 2016]) greater than dorsal vertebrae of MOR2 (L/H: 1.04-1.28) and have more rounded and proportionally wider articular faces. Even though the ratio $\mathrm{L} / \mathrm{H}$ of Valdosaurus certainly overlaps with those of MOR2 in the most posterior dorsal centra (Valdosaurus: IWCMS 2013.175, L/H: 1.18-1.87), they exhibit sub-circular anterior and posterior faces (Barrett, 2016). Similarly, proximal caudals of Hypsilophodon, basal rhabdodontomorphans and Valdosaurus have a $\mathrm{L} / \mathrm{H}$ ratio (Hypsilophodon: 1.22-1.33 in Fig. 30 in Galton [1974]; basal rhabdodontomorphans: 1.41-1.93 in MDS. VG 72 and 101 [Dieudonné et al., 2016]; Valdosaurus: 1.18 in the 6th of IWCMS 2013.175 [Barrett, 2016]) greater than those of MOR1 (L/H: 0.85-0.99). Moreover, the middle caudal centra of Hypsilophodon do not show the typical hexagonal articular faces of iguanodontians (Norman, 2004), in contrast with MOR1. It should be noted that the unique specimen of the basal ornithopod Gideonmantellia amosanjuanae Ruiz-Omeñaca et al., 2012, which was described in the lower Barremian (Camarillas Formation) of the nearby locality of Galve (Teruel, Spain), is an immature individual (Ruiz-Omeñaca et al., 2012) but can be totally differentiated from MOR1 and MOR2 for the reasons explained regarding Hypsilophodon.

Both MOR1 and MOR2 share more features with dorsal and caudal vertebrae of large non-hadrosaurid styracosternans described in the Hauterivian-Barremian of the Iberian Peninsula than with any other group discussed. Next, taxonomic affinities of both morphotypes with other taxa will be discussed independently. Overall, the caudal centra of MOR1 closely resemble those of several iguanodontians (but unlike basal ornithopods such as Hypsilophodon [Galton, 1974]) in having higher-than-long anterior centra that become enlarged in the middle vertebrae of the series. This feature is not only extensively present in European genera of large non-hadrosaurid styracosternans such as Barilium (Norman, 2011), Hypselospinus (Norman, 2015), Magnamanus (Fuentes et al., 2016), Iguanodon (Norman, 1980), and Mantellisaurus (Norman, 1986), but also in several other iguanodontians, e.g., Zalmoxes (Weishampel et al., 2003; Godefroit et al., 2009), Tenontosaurus (Forster, 1990), Camptosaurus (Gilmore, 1909; Carpenter \& Wilson, 2008), Ouranosaurus (Taquet, 1976; Bertozzo et al., 2017), Eolambia (McDonald et al., 2012), and Bactrosaurus (Godefroit et al., 1998). This consistency of the lateral shape in the caudal vertebrae along iguanodontian evolution might explain why the multivariate analysis concentrates the caudal morphospace for almost all the taxa analysed when the size effect is removed (Fig. 6b). The English Valanginian genus Barilium is characterized by having autapomorphic wider-than-high sub-rectangular articular faces in the first caudal (Norman, 2011). Although the first caudal in MOR1 is incomplete (Fig. 2a), it does not seem to be proportionally as wide as that in Barilium and it closely resembles the squared shape described in Iguanodon (Norman, 1980; Verdú, 2017; Verdú et al., 2017) or Mantellisaurus (Norman, 1986). MOR1 have platycoelous caudal vertebrae such as those of the Iberian taxa Magnamanus (Fuentes et al., 2016) and I. bernissartensis (Norman, 1980). Evidence for the affinity of MOR1 with Magnamanus and Iguanodon is also present in the morphometric study when size is considered (Fig. 6a), even though the type of articular faces is not analysed. Additionally, the platycoelous caudal vertebrae of MOR1 are identical to those of the Iguanodon sp. indet. specimen ('Delapparentia turolensis' Ruiz-Omeñaca, 2011) described in the lower Barremian (Camarillas Formation) of the nearby locality of Galve (Verdú et al., 2017). Anterior-to-middle caudals are amphiplatyan (slightly platycoelous) in perinates referred to the Iberian Barremian taxon I. galvensis, but this feature might be ontogenetically variable and adult caudal vertebrae are currently undescribed (Verdú, 2017). Platycoelus centra in anterior caudals are also present in 
basal iguanodontians such as Zalmoxes (Weishampel et al., 2003) and Tenontosaurus (Forster, 1990), but centra in MOR1 are significantly bigger. In contrast, anterior caudal centra are amphiplatyan in the middle-sized taxon Mantellisaurus (Norman, 1986), of which fossils have also been described in the upper Barremian of the Iberian Peninsula (Llandres et al., 2013; Gasulla et al., 2014), and in the robust English and Valanginian genus Barilium (Norman, 2011). The deep ventral sulcus present in some middle caudal centra of MOR1 (e.g., MAP-4548, Fig. 3c) does not have systematic value because it was reported as individually variable (Verdú et al., 2017). Unfortunately, caudal vertebrae have not been described in the large Iberian styracosternans Morelladon (Gasulla et al., 2015) and Proa (McDonald et al., 2012).

Dorsal vertebrae of MOR2 are like those of Morelladon (Gasulla et al., 2015) and Mantellisaurus (Norman, 1986) in having longer-than-high middle-to-posterior dorsal centra, but they are different from those having higher-than-long middle-to-posterior dorsal centra, such as Magnamanus (Fuentes et al., 2016), I. galvensis (Verdú, 2017), and I. bernissartensis (Norman, 1980). This observation agrees with the morphometric study of the dorsal vertebrae when size effect is considered. Here, MOR2 occupies a similar morphospace as Mantellisaurus and Morelladon, being particularly overlapped with the latter (Fig. 6c). Longer-than-high cylindrical middle-toposterior centra is present in several other iguanodontian genera, including Zalmoxes (Weishampel et al., 2003; Godefroit et al., 2009), Valdosaurus (Barrett, 2016), Camptosaurus (Carpenter \& Wilson, 2008), Hippodraco (McDonald et al., 2010), and Ouranosaurus (Taquet, 1976; Bertozzo et al., 2017). Nevertheless, middle-to-posterior dorsal vertebrae are amphiplatyan in Mantellisaurus (Norman, 1986), unlike those of MOR2, which are platycoelous, similar to those of Morelladon (Gasulla et al., 2015). In contrast, Magnamanus (Fuentes et al., 2016), I. cf. galvensis (Verdú, 2017), and I. bernissartensis (Norman, 1980) have amphiplatyan dorsal vertebrae. Platycoelous dorsal vertebrae have been only described in the non-hadrosaurid iguanodontians Tenontosaurus (Forster, 1990; Winkler et al., 1997) and Hippodraco (McDonald et al., 2010), apart from Morelladon. Additionally, MOR2 exhibits a ventral keel in the dorsal vertebrae similar to Mantellisaurus (Norman, 1986), Morelladon (Gasulla et al., 2015), and I. bernissartensis (Norman, 1980). In contrast, this feature is absent in the dorsal vertebrae of Magnamanus (Fuentes et al., 2016) and in I. cf. galvensis (Verdú, 2017). Moreover, the ventral keel feature in the dorsal vertebrae is broadly extended among iguanodontians, e.g., Zalmoxes (Weishampel et al., 2003; Godefroit et al., 2009), Tenontosaurus (Forster, 1990), Cumnoria (Galton \& Powell, 1980), Barilium (Norman, 2011), Hypselospinus (Norman, 2015), Ouranosaurus (Taquet, 1976; Bertozzo et al., 2017), and Bactrosaurus
(Godefroit et al., 1998). MOR2 dorsal centra are also very similar to the platycoelous vertebrae of GPIT 1802/1-7 found in beds of similar age from Salas de los Infantes (Burgos, Spain) (Pereda-Suberbiola et al., 2011) and which closely resemble those of Morelladon (Gasulla et al., 2015). Dorsal centra of GPIT 1802/1-7 are resolved in the same sector as those of MOR2 in the morphometric study but they do not overlap it, perhaps either due to intraspecific variation or because they belong to different parts of the dorsal series.

The caudal vertebra of MOR2 is resolved in the area occupied by Mantellisaurus, as well as MOR1 and Magnamanus. Similarity of the caudal vertebra of MOR2 with those of Mantellisaurus is not surprising as it is also observed for the dorsal vertebrae. In contrast, recovered relation with Magnamanus and MOR1 is striking and might have been due to the similar proportion among some elements of the caudal series in these taxa. The anterior caudal centrum of MOR2 is amphicoelous and it differs from those amphiplatyan in Mantellisaurus (Norman, 1986) or those platycoelous in Magnamanus (Fuentes et al., 2016) and I. bernissartensis (Norman, 1980). Unfortunately, caudal vertebrae are unknown in Morelladon (Gasulla et al., 2015), but amphicoelus caudal vertebrae might be one of its features. Camptosaurus (Gilmore, 1909) and Ouranosaurus (Taquet, 1976; Bertozzo et al., 2017) are unique non-hadrosaurid iguanodontian genera with amphicoelous anterior caudals.

Hence, MOR1 and MOR2 cannot be classified with more precision than that of Iguanodontia indet. when considering only anatomical features. A summary of those characters which suggest iguanodontian affinity include the following: caudal centra of MOR1, which are anteroposteriorly compressed in the anterior vertebrae but which elongate toward the middle part of the tail; middle caudals, according to Norman (2004), which acquire hexagonal articular faces; and dorsal centra of MOR2, tall in lateral view (more than in basal ornithopods), with higherthan-wide elliptical articular faces and with the presence of a ventral keel. However, their Lower Cretaceous age, when the abundance and diversity of styracosternans was high in the Iberian Peninsula, and the similarity of MOR1 and MOR2 with sympatric styracosternan genera allow us to classify them tentatively as Styracosterna indet. Note that Cobos et al. (2012) classified the fossils from CT-16 (here MOR2) as Hadrosauriformes indet. However, we consider it more appropriate to include the fossils in a more inclusive clade with further support by phylogenetic studies. As such, the classification is Styracosterna (e.g. Verdú et al., 2018). Even though MOR1 and MOR2 share proportions and configuration of articular faces with Magnamanus/Iguanodon and Morelladon respectively, it is better to be conservative when working with fossils that are so fragmentary and not propose genera/specific assignations to avoid the introduction of taxonomic noise. 
Several authors have reported relevant ontogenetic changes that affected the axial skeleton during growth in some small and large-sized iguanodontians (e.g., Dewaele et al., 2015; Verdú, 2017; Hübner, 2018). Since vertebrae of MOR2 are smaller than those of MOR1, they might belong to an immature specimen of the latter rather than to a different taxon. For this reason, the determination of the approximate ontogenetic stage of studied fossils is crucial for discriminating between systematic informative characters and those that are ontogenetically variable. In this sense, the size of the fossils and the pattern of closure of the neurocentral suture (i.e., the degree of fusion of the neural arch with its centrum) are good qualitative indicators of the degree of development in ornithopods (Verdú, 2017 and references therein). All caudal vertebrae of MOR1 have their neurocentral sutures totally closed, including those in the most anterior region of the series. The fusion of the neural arch to the centra in these vertebrae occurred between the juvenile and sub-adult stages in Iguanodon (Verdú, 2017). However, the size of the caudal centra of MOR1 reveals that it might be even older than a sub-adult since they are larger (e.g., MAP797, $120 \mathrm{~mm}$ of length) than those of big 'adult' specimens of I. bernissartensis (e.g., RBNS R51, $104 \mathrm{~mm}$ [Norman, 1986]) or Magnamanus (e.g., MNS 2000/132.2, $112.8 \mathrm{~mm}$ [Fuentes et al., 2016]). Thus, vertebrae of MOR1 likely belonged to a fully-growth adult.

In the case of MOR2, specimens from CT-16 and CT-17 are similar in size, so it is assumed that they had roughly the same somatic age. All the dorsal vertebrae of MOR2 have the neurocentral sutures closed (except for MAP816 , which has the sutures partially closed), including MAP-3907, which is tentatively identified as an anteriorto-middle dorsal vertebra. Closure of the neurocentral suture in the anterior dorsal vertebrae occurred late in Iguanodon development, specifically between the sub-adult and adult stages (Verdú, 2017). Moreover, the length of the dorsal (e.g., MAP-816, $90.8 \mathrm{~mm}$ ) and caudal vertebrae (MAP-3906, $76.6 \mathrm{~mm}$ ) of MOR2 is compatible with that of supposed 'adult' specimens of the middle-sized iguanodontians Mantellisaurus (e.g., RBINS R57, dorsal: $80 \mathrm{~mm}$, caudal: $79 \mathrm{~mm}$ [Norman, 1986]) and Morelladon (e.g., CMP-MS-03-09, dorsal: $93.5 \mathrm{~mm}$ ). Thus, the middlesized specimen MOR2 can be confidently attributed to a mature specimen as MOR1, and therefore it does not represent an immature specimen of the later morphotype. Consequently, all anatomical differences observed between the caudal vertebrae of MOR1 and MOR2 can be considered systematically significant, including the size of the centra, and similarities reported with other taxa are not a product of ontogeny.

Finally, evidence from the southern region of the Maestrazgo Basin provided in this work further supports to the hypothesis of coexistence of two forms of large ornithopods during the late Hauterivian-early Barremian in the Iberian Peninsula as was previously observed in the western part of the Cameros Basin (PeredaSuberbiola et al., 2011, 2012; Fuentes et al., 2016): a robust styracosternan related to Magnamanus/Iguanodon and a slender one related to Morelladon. However, it should be noted that Magnamanus is anatomically very similar to Iguanodon, and future reviews of the holotype might shed light on a closer relationship between them than previously thought (Verdú, 2017). According to evidence derived from the study of different iguanodontian dentary teeth, the diversity of styracosternans might ascend to three taxa in the lower Barremian (Gasca et al., 2014). Similarly, younger upper Barremian deposits in Spain have also yielded fossils of the large and robust I. bernissartensis (Gasulla et al., 2014) and two slender taxa, Mantellisaurus (Llandres et al., 2013; Gasulla et al., 2014) and Morelladon (Gasulla et al., 2015). As for Magnamanus, fragmentary remains from the Iberian Peninsula assigned to Mantellisaurus might be related to Morelladon in future studies given the close phylogenetic relationship between both taxa. In the same way as this study, Rey et al. (2018) also identified two different styracosternan morphotypes (one robust and other slender) in the Albian of Teruel (Spain), based on fragmentary vertebral remains. In fact, Norman (2012) already observed the recurrent record of both a robust and a slender large styracosternan associated in the Wealden Group of the southern England: Barilium and Hypselospinus in the Valanginian, and I. bernissartensis and Mantellisaurus in the Barremian-lower Aptian. Similar association of styracosternans is also found in the Sainte-Barbe Clays Formation (upper Barremian-lower Aptian) of Belgium: I. bernissartensis and Mantellisaurus (Norman, 2012).

\section{CONCLUSIONS}

We have systematically and morphometrically studied a sample of large-ornithopod dorsal and caudal vertebral centra found in the upper Hauterivian-lower Barremian (Lower Cretaceous) deposits of the southern margin of the Maestrazgo Basin (northeastern Teruel, Spain). They correspond to at least three mature (or almost mature) individuals of two different but indeterminate iguanodontians, MOR1 and MOR2, which are ascribed tentatively to the more inclusive clade of Styracosterna.

First, MOR1 is represented by several caudal centra, which can be related to the robust and large Iberian styracosternans Magnamanus (from the upper Hauterivianlower Barremian) and Iguanodon (from the BarremianAptian) because of the values of their $\mathrm{L} / \mathrm{H}$ ratio and their platycoelous anterior caudals. Morphometric study with a multivariate PCA also shows morphological affinity of 
these two taxa with MOR1, but not when size effect is removed, perhaps because proportions of caudal vertebrae are consistent along iguanodontian phylogeny.

The second styracosternan, MOR2, is represented by dorsal and caudal centra. The dorsals of MOR2 resemble those of the sail-backed styracosternan from the upper Barremian Morelladon in their $\mathrm{L} / \mathrm{H}$ ratio and their platycoelus articular faces. Morphometric study with a multivariate PCA also supports this observation for the dorsal vertebrae of MOR2, at least when size is considered. Anterior caudal of MOR2 is amphicoelus unlike MOR1.

Thus, this study provides further support, using evidence recorded in the El Castellar Formation, for the hypothesis that two forms of large styracosternans coexisted in sympatry during the late Hauterivian-early Barremian in what is today the Iberian Peninsula. In future research, incorporation of either additional lineal measurements taken along vertebrae (including those in the neural arch) or 3D geometric morphometric methods might convert multivariate analysis into a useful tool for identifying the taxonomical affinities of isolated ornithopod vertebrae.

\section{ACKNOWLEDGEMENTS}

This research was funded by the Comisión de Ayudas a la Investigación de la Sociedad Española de Paleontología (AJISEP-2017-07144), the Departamento de Educación, Cultura y Deporte (Gobierno de Aragón), Research Group E04_17R FOCONTUR financed by the Departamento de Innovación, Investigación y Universidad (Gobierno de Aragón) and FEDER Aragón 2014-2020 ('Construyendo Europa desde Aragón'), the Instituto Aragonés de Fomento, the Spanish Ministerio de Economía y Competitividad (GL2013-41295-P, Project DINOTUR, CGL201452670-P), and the Spanish Ministerio de Ciencia e Innovación y Universidades (PGC2018-094034-B-C22). The authors thank Pascal Godefroit, Annelise Folie and all the RBINS staff for providing access to the Bernissart iguanodontian collection, and Jaume Grau for his collaboration. Finally, authors appreciate useful comments and suggestions made by the associated editor, Gonzalo Jiménez-Moreno, and the reviewers Xabier Pereda Suberbiola and Penélope Cruzado Caballero.

\section{REFERENCES}

Alcalá, L., Cobos, A. \& Royo-Torres, R. 2018. Dinosaurios de la Península Ibérica. Revista PH, 94, 116-153; doi: 10.33349/2018.0.4145.
Barrett, P.M. 2016. A new specimen of Valdosaurus canaliculatus (Ornithopoda: Dryosauridae) from the Lower Cretaceous of the Isle of Wight, England. Memoirs of Museum Victoria, 74, 29-48; doi: 10.24199/j. mmv.2016.74.04.

Barrett, P.M., Evans, D.C. \& Head, J.J. 2014. A re-evaluation of purported hadrosaurid dinosaur specimens from the "Middle" Cretaceous of England. In: Hadrosaurs (eds. Eberth, D.A. \& Evans, C.D.). Indiana University Press, Bloomington and Indianapolis, 96-107

Bertozzo, F., Dalla-Vecchia, F.M. \& Fabbri, M. 2017. The Venice specimen of Ouranosaurus nigeriensis (Dinosauria, Ornithopoda). PeerJ, 5, e3403; doi: 10.7717/ peerj.3403.

Blanco, A., Prieto-Márquez, A. \& De Esteban-Trivigno, S. 2015. Diversity of hadrosauroid dinosaurs from the Late Cretaceous Ibero-Armorican Island (European Archipelago) assessed from dentary morphology. Cretaceous Research, 56, 447-457; doi: 10.1016/j. cretres.2015.04.001.

Boyd, C.A. 2015. The systematic relationships and biogeographic history of ornithischian dinosaurs. PeerJ, 3, e1523; doi: 10.7717/peerj.1523.

Brink, K.S., Zelenitsky, D.K., Evans, D.C., Horner, J.R. \& Therrien, F. 2014. Cranial morphology and variation in Hypacrosaurus stebingeri (Ornithischia: Hadrosauridae). In: Hadrosaurs (eds. Eberth, D.A. \& Evans, C.D.). Indiana University Press, Bloomington and Indianapolis, 245-267.

Butler, R.J., Upchurch, P. \& Norman. D.B. 2008. The phylogeny of the ornithischian dinosaurs. Journal of Systematic Palaeontology, 6, 1-40; doi: 10.1017/ S1477201907002271.

Campos-Soto, S., Cobos, A., Caus, E., Benito, M.I., Fernández-Labrador, L., Suárez-González, P., Quijada, I.E., Mas, R., Royo-Torres, R. \& Alcalá, L. 2017. Jurassic Coastal Park: A great diversity of palaeoenvironments for the dinosaurs of the Villar del Arzobispo Formation (Teruel, eastern Spain). Palaeogeography, Palaeoclimatology, Palaeoecology, 485, 154-177; doi: 10.1016/j.palaeo.2017.06.010.

Canudo, J.I., Royo-Torres, R. \& Cuenca-Bescós, G. 2008. A new sauropod: Tastavinsaurus sanzi gen. et sp. nov. from the Early Cretaceous (Aptian) of Spain. Journal of Vertebrate Paleontology, 28, 712-731; doi: 10.1671/0272-4634(2008)28[712:ANSTSG]2.0.CO;2.

Carpenter, K. \& Wilson, Y. 2008. A new species of Camptosaurus (Ornithopoda: Dinosauria) from the Morrison Formation (Upper Jurassic) of Dinosaur National Monument, Utah, and a biomechanical analysis of its forelimb. Annals of the Carnegie Museum, 76, 227-263; doi: 10.2992/0097-4463(2008)76[227:ANSO $\mathrm{CO} 2.0 . \mathrm{CO} ; 2$.

Charig, A.J. \& Milner, A.C. 1997. Baryonyx walkeri, a fisheating dinosaur from the Wealden of Surrey. Bulletin of the Natural History Museum, 53, 11-70.

Cobos, A., Royo-Torres, R. \& Alcalá, L. 2012. Restos postcraneales de ornitópodo en el Cretácico Inferior de El 
Castellar (Subcuenca de Peñagolosa, Teruel). Geogaceta, 52, 181-184.

Coria, R.A. \& Salgado, L. 1996. A basal iguanodontian (Ornithischia: Ornithopoda) from the Late Cretaceous of South America. Journal of Vertebrate Paleontology, 16, 445-457; doi: 10.1080/02724634.1996.10011333.

Cuesta, E., Ortega, F. \& Sanz, J.L. 2019. Axial osteology of Concavenator corcovatus (Theropoda; Carcharodontosauria) from the Lower Cretaceous of Spain. Cretaceous Research, 95, 106-120; doi: 10.1016/j. cretres.2018.10.026.

Dewaele, L., Tsogtbaatar, K., Barsbold, R., Garcia, G., Stein, K., Escuillié, F. \& Godefroit, P. 2015. Perinatal specimens of Saurolophus angustirostris (Dinosauria: Hadrosauridae) from the Upper Cretaceous of Mongolia. PLOS ONE, 10, e0138806; doi: 10.1371/journal.pone.0138806.

Dieudonné, P.E., Tortosa, T., Torcida Fernández-Baldor, F., Canudo, J.I. \& Díaz-Martínez, I. 2016. An Unexpected Early Rhabdodontid from Europe (Lower Cretaceous of Salas de los Infantes, Burgos Province, Spain) and a Re-Examination of Basal Iguanodontian Relationships. PLoS ONE, 11(6), e0156251; doi: 10.1371/journal. pone. 0156251

Dollo, L. 1888. Iguanodontidae et Camptonotidae. Comptes Rendus de Academie des Sciences, Paris, 106, 775-777.

Escaso, F., Ortega, F., Dantas, P., Malafaia, E., Silva, B., Gasulla, J.M., Mocho, P., Narváez, I. \& Sanz, J.L. 2014. A new dryosaurid ornithopod (Dinosauria, Ornithischia) from the Late Jurassic of Portugal. Journal of Vertebrate Paleontology, 34, 1102-1112; doi: 10.1080/02724634.2014.849715.

Fearon, J.L. \& Varricchio, D.J. 2015. Morphometric analysis of the forelimb and pectoral girdle of the Cretaceous ornithopod dinosaur Oryctodromeus cubicularis and implications for digging. Journal of Vertebrate Paleontology, 35, e936555; doi: 10.1080/02724634.2014.936555.

Forster, C.A. 1990. The postcranial skeleton of the ornithopod dinosaur Tenontosaurus tilletti. Journal of Vertebrate Paleontology, 10, 273-294; doi: 10.1080/02724634.1990.10011815.

Fuentes, C., Meijide, M., Meijide, F. \& Meijide, M. 2016. Un nuevo dinosaurio estiracosterno (Ornithopoda: Ankylopollexia) del Cretácico Inferior de España. Spanish Journal of Palaeontology, 31, 407-446.

Galton, P.M. 1974. The ornithischian dinosaur Hypsilophodon from the Wealden of the Isle of Wight. Bulletin of the British Museum (Natural History). Geology, 25, 1-152.

Galton, P.M. 2009. Notes on Neocomian (Lower Cretaceous) ornithopod dinosaurs from England - Hypsilophodon, Valdosaurus, "Camptosaurus," "Iguanodon" - and referred specimens from Romania and elsewhere. Revue de Paléobiologie, 28, 211-273.

Galton, P.M. \& Powell, H.P. 1980. The ornithischian dinosaur Camptosaurus prestwichii from the Upper Jurassic of England. Palaeontology, 23, 411-443.

Gasca, J.M. 2011. Descripción de una tibia de dinosaurio ornitópodo de la Formación El Castellar (Cretácico Inferior, Teruel). XXVII Jornadas de la Sociedad Española de Paleontología: Simposios de los Proyectos PICG 587 y 596, Abstract Book, pp. 179-183.

Gasca, J.M., Canudo, J.I. \& Moreno-Azanza, M. 2009. Dientes aislados de dinosaurio de la Formación El Castellar en Miravete de la Sierra (Cretácico Inferior, Teruel, España). Actas de las IV Jornadas Internacionales sobre Paleontología de Dinosaurios y su Entorno Salas de los Infantes, Burgos, Abstract Book, pp. 221-234.

Gasca, J.M., Canudo, J.I. \& Moreno-Azanza, M. 2014. On the diversity of Iberian iguanodont dinosaurs: New fossils from the lower Barremian, Teruel province, Spain. Cretaceous Research, 50, 264-272; doi: 10.1016/j. cretres.2014.05.009.

Gasulla, J.M. 2015. Los dinosaurios de la Cantera del Mas de la Parreta, Morella (Formación Morella, Barremiense superior, Cretácico Inferior): Sistemática, análisis filogenético e implicaciones paleobiológicas. Ph.D. Thesis, Universidad Autónoma de Madrid (unpublished).

Gasulla, J.M., Ortega, F., Pereda-Suberbiola, X., Escaso, F. \& Sanz, J.L. 2011. Elementos de la armadura dérmica del dinosaurio anquilosaurio Polacanthus Owen, 1865 en el Cretácico Inferior de Morella (Castellón, España). Ameghiniana, 48, 508-519; doi: 10.5710/AMGH. v48i4(276).

Gasulla, J.M., Escaso, F., Ortega, F. \& Sanz, J.L. 2014. New hadrosauriform cranial remains from the Arcillas de Morella Formation (lower Aptian) of Morella, Spain. Cretaceous Research, 47, 19-24; doi: 10.1016/j. cretres.2013.10.004.

Gasulla, J.M., Escaso, F., Narváez, I., Ortega, F. \& Sanz, J.L. 2015. A new sail-backed styracosternan (Dinosauria: Ornithopoda) from the Early Cretaceous of Morella, Spain. PLoS ONE, 10, e0144167; doi: 10.1371/journal. pone.0144167.

Gilmore, C.W. 1909. Osteology of the Jurassic reptile Camptosaurus, with a revision of the species of the genus, and descriptions of two new species. Proceedings of the United States National Museum, 36, 197-332; doi: 10.5479/si.00963801.36-1666.197.

Godefroit, P., Dong, Z.M., Bultynck, P., Li, H. \& Feng, L. 1998. New Bactrosaurus (Dinosauria: Hadrosauroidea) material from Iren Dabasu (Inner Mongolia, P. R. China). Bulletin de l'Institut Royal des Sciences Naturelles de Belgique, Sciences de la Terre, 68(Supplément), 3-70.

Godefroit, P., Codrea, V. \& Weishampel, D.B. 2009. Osteology of Zalmoxes shqiperorum (Dinosauria, Ornithopoda), based on new specimens from the Upper Cretaceous of Nălaţ-Vad (Romania). Geodiversitas, 31, 525-553; doi: $10.5252 / \mathrm{g} 2009 \mathrm{n} 3 \mathrm{a} 3$.

Guerrero, A. \& Cobos, A. 2017. Nuevos fósiles de dinosaurios cretácicos del yacimiento La Balsa 2 (El Castellar, Teruel, España). XV Encuentro de Jóvenes Investigadores en Paleontología, Abstract Book, pp.185-189.

Hammer, Ø. 2018. PAST: Paleontological Statistics Version 3.21. Reference Manual. 264 pp.

Hammer, Ø., Harper, D.A.T. \& Ryan, P.D. 2001. PAST: Paleontological statistics software package for education and data analysis. Palaeontologia Electronica, 4, 1-9. 
Hooley, R.W. 1925. On the skeleton of Iguanodon atherfieldensis sp. nov., from the Wealden Shales of Atherfield (Isle of Wight). Quarterly Journal of the Geological Society, 81, $1-61$.

Hübner, T. 2018. The postcranial ontogeny of Dysalotosaurus lettowvorbecki (Ornithischia: Iguanodontia) and implications for the evolution of ornithopod dinosaurs. Palaeontographica Abteilung A, 310, 43-120; doi: 10.1127/ pala/2018/0072.

Hulke, J.W. 1881. Polacanthus foxii, a large undescribed dinosaur from the Wealden formation in the Isle of Wight. Philosophical Transactions of the Royal Society of London, 172, 653-662; doi: 10.1098/rstl.1881.0015.

Knoll, F. 2009. A large iguanodont from the Upper Barremian of the Paris Basin. Geobios, 42, 755-764; doi: 10.1016/j. geobios.2009.06.002.

Llandres, M., Vullo, R., Marugán-Lobón, J., Ortega, F. \& Buscalioni, A.D. 2013. An articulated hindlimb of a basal iguanodont (Dinosauria, Ornithopoda) from the Early Cretaceous Las Hoyas Lagerstätte (Spain). Geological Magazine, 150, 572-576; doi: 10.1017/ S0016756813000095.

Luque, L., Espílez, E., Cobos, A., Alcalá, A., Royo-Torres, R., Aberasturi, A., Mampel, L. \& González, A. 2006. Iguanodóntidos y otros vertebrados cretácicos de Miravete de la Sierra (Teruel). Teruel, 91, 57-87.

Martín-Closas, C. 1989. Els caròfits del Cretaci Inferior de les conques perifèriques del Bloc de l'Ebre. Ph.D. Thesis, Universitat de Barcelona, Barcelona (unpublished).

Marsh, O. 1882. Classification of the Dinosauria. American Journal of Sciences, 3, 81-86; doi: 10.2475/ajs.s3-23.133.81.

McDonald, A.T., Kirkland, J.I., DeBlieux, D.D., Madsen, S.K., Cavin, J., Milner, A.R.C. \& Panzarin, L. 2010. New basal iguanodonts from the Cedar Mountain Formation of Utah and the evolution of thumb-spiked dinosaurs. PLOS ONE, 5, e14075; doi: 10.1371/journal.pone.0014075.

McDonald, A.T., Espílez, E., Mampel, L., Kirkland, J.I. \& Alcalá, L. 2012. An unusual new basal iguanodontian (Dinosauria: Ornithopoda) from the Lower Cretaceous of Teruel, Spain. Zootaxa, 3595, 61-76.

Norman, D.B. 1980. On the ornithischian dinosaurs Iguanodon bernissartensis from the Lower Cretaceous of Bernissart (Belgium). Memoires de l'Institut Royal des Sciences Naturelles de Belgique, 178, 1-103.

Norman, D.B. 1986. On the anatomy of Iguanodon atherfieldensis (Ornithischia: Ornithopoda). Bulletin de l'Institut Royal des Sciences Naturelles de Belgique, 56, 281-372.

Norman, D.B. 2004. Basal iguanodontia. In: The Dinosauria (eds. Weishampel, D.B., Dodson, P. \& Osmólska, H.). University of California Press, Berkeley CA, 413-437.

Norman, D.B. 2011. On the osteology of the Lower Wealden (Valanginian) iguanodontian Barilium dawsoni (Iguanodontia: Styracosterna). In: Studies on Fossil Tetrapods (eds. Barrett, P.M. \& Milner, A.R.). Special Papers in Palaeontology, 86, 165-194.

Norman, D.B. 2012. Iguanodontian taxa (Dinosauria: Ornithischia) from the Lower Cretaceous of England and
Belgium. In: Bernissart Dinosaurs and Early Cretaceous Terrestrial Ecosystems (ed. Godefroit, P.). Indiana University Press, Bloomington, 174-212.

Norman, D.B. 2015. On the history, osteology and systematic position of the Wealden (Hastings group) dinosaur Hypselospinus fittoni (Iguanodontia: Styracosterna). Zoological Journal of the Linnean Society, 173, 92-189; doi: 10.1111/zoj.12193.

Ortega, F., Escaso, F. \& Sanz, J.L. 2010. A bizarre, humped Carcharodontosauria (Theropoda) from the Lower Cretaceous of Spain. Nature, 467, 203-206; doi: 10.1038/ nature09181.

Owen, R. 1842. Report on British fossil reptiles, Part II. Report of the Eleventh Meeting of the British Association Advancement of the Science, 60-204.

Paul, G.S. 2008. A revised taxonomy of the iguanodont dinosaur genera and species. Cretaceous Research, 29, 192-216; doi: 10.1016/j.cretres.2007.04.009.

Pereda-Suberbiola, X. 1994. Polacanthus (Ornithischia, Ankylosauria), a transatlantic armoured dinosaur from the Early Cretaceous of Europe and North America. Palaeontographica Abteilung A, 232, 133-159.

Pereda-Suberbiola, X., Ruiz-Omeñaca, J.I., Torcida FernándezBaldor, F., Maisch, M.W., Huerta, P., Contreras, R., Izquierdo, L.A., Montero Huerta, D., Urien Montero, V. \& Welle, J. 2011. A tall-spined ornithopod dinosaur from the Early Cretaceous of Salas de los Infantes (Burgos, Spain). Comptes Rendus Palevol, 10, 551-558; doi: 10.1016/j. crpv.2011.04.003.

Pereda-Suberbiola, X., Ruiz-Omeñaca, J.I., Canudo, J.I., Torcida, F. \& Sanz, J.L. 2012. Dinosaur faunas from the Early Cretaceous (Valanginian-Albian) of Spain. In: Bernissart Dinosaurs and Early Cretaceous Terrestrial Ecosystems (ed. Godefroit, P.). Indiana University Press, Bloomington, 379-407.

Prieto-Márquez, A. 2010. Global phylogeny of Hadrosauridae (Dinosauria: Ornithopoda) using parsimony and Bayesian methods. Zoological Journal of the Linnean Society, 159, 435-502; doi: 10.1111/j.1096-3642.2009.00617.x.

Rey, G., Royo-Torres, R. \& Alcalá, L. 2018. Nuevos restos de dinosaurios estiracosternos en el Albiense de la Cordillera Ibérica. Geogaceta, 63, 83-86.

Royo-Torres, R. 2009. El Saurópodo de Peñarroya de Tastavins. Instituto de Estudios Turolenses \& Fundación Conjunto Paleontológico de Teruel-Dinópolis, Teruel.

Royo-Torres, R., Fuentes, C., Meijide, M., Meijide-Fuentes, F. \& Meijide-Fuentes, M. 2017. A new Brachiosauridae sauropod dinosaur from the Lower Cretaceous of Europe (Soria Province, Spain). Cretaceous Research, 80, 38-55; doi: 10.1016/j.cretres.2017.08.012.

Ruiz-Omeñaca, J.I. 2011. Delapparentia turolensis nov. gen. et sp., a new iguanodontoid dinosaur (Ornithischia: Ornithopoda) from the Lower Cretaceous of Galve (Spain). Estudios Geológicos, 67, 83-110; doi: 10.3989/ egeol.40276.124.

Ruiz-Omeñaca, J.I., Canudo, J.I., Cuenca-Bescós, G., Cruzado-Caballero, P.L., Gasca, J.M. \& Moreno-Azanza, M. 2012. A new basal ornithopod dinosaur from the 
Barremian of Galve, Spain. Comptes Rendus Palevol, 11, 435-444; doi: 10.1016/j.crpv.2012.06.001.

Salas, R. 1987. El Malm i el Cretaci inferior entre el Massís de Garraf i la Serra d'Espadà. Anàlisi de Conca. Ph.D. Thesis, Universitat de Barcelona, Barcelona (unpublished).

Salas, R. \& Guimerà, J. 1996. Rasgos estructurales principales de la cuenca Cretácica Inferior del Maestrazgo (Cordillera Ibérica oriental). Geogaceta, 20, 1704-1706.

Sanguino, F. \&. Buscalioni, Á.D. 2018. The Iguanodon locality of Barranco Pata la Mona (upper Barremian, Buenache de la Sierra, Cuenca) revisited. XVI Encuentro de Jóvenes Investigadores en Paleontología, Abstract Book, pp.103-106.

Sanz, J.L., Casanovas, M.I. \& Santafé, J.V. 1982. Paleontología. In: Geología y Paleontología (Dinosaurios) de las Capas Rojas de Morella (Castellón, España) (eds. Santafé, J.V., Casanovas, M.L., Sanz, J.L. \& Calzada, S.). Diputación Provincial de Castellón y Diputación de Barcelona, Castellón, Barcelona, 69-169.

Sanz, J.L., Santafé, J.V. \& Casanovas, L. 1983. Wealden ornithopod dinosaur Hypsilophodon from the Capas Rojas Formation (Lower Aptian, Lower Cretaceous) of Morella, Castellon, Spain. Journal of Vertebrate Paleontology, 3, 39-42; doi: 10.1080/02724634.1983.10011956.

Seeley, H.G. 1887. On the classification of the fossil animals commonly named Dinosauria. Proceedings of the Royal Society of London, 43, 165-171; doi: 10.1098/ rspl.1887.0117.

Sereno, P.C. 1986. Phylogeny of the bird-hipped dinosaurs (Order Ornithischia). National Geographic Research, 2, 234-256.

Sereno, P.C. 1998. A rationale for phylogenetic definitions, with application to the higher-level taxonomy of Dinosauria. Neues Jahrbuch für Geologie und Paläontologie, 210, 41-83; doi: 10.1127/njgpa/210/1998/41.

Sereno, P.C. 2005. TaxonSearch [accessed 2019 Apr 17]. Available from: http://taxonsearch.uchicago.edu/.

Taquet, P. 1976. Géologie et paléontologie du gisement de Gadoufaoua (Aptien du Niger). Cahiers de Paléontologie. CNRS, Paris.

Torcida Fernández-Baldor, F., Izquierdo Montero, L.A., Contreras Izquierdo, R., Huerta, P., Montero Huerta,
D., Pérez Martínez, G. \& Urén Montero, V. 2006. Un dinosaurio "iguanodóntido" del Cretácico Inferior de Burgos (España). Actas de las III Jornadas sobre Dinosaurios y su Entorno, Abstract Book, 349-363.

Van Beneden, P.J. 1881. Sur l'arc pelvien chez les dinosauriens de Bernissart (review of G. A. Boulenger). Bulletin de l'Academie Royale des Sciences, des Lettres et des BeauxArts de Belgique (3rd ser.), 1, 600-608.

VanBuren, C.S. \& Bonnan, M. 2013. Forearm posture and mobility in quadrupedal dinosaurs. PLoS ONE, 8, e74842; doi: 10.1371/journal.pone.0074842.

Verdú, F.J. 2017. Sistemática, filogenia y paleobiología de Iguanodon galvensis (Ornithopoda, Dinosauria) del Barremiense inferior (Cretácico Inferior) de Teruel (España). Ph.D. Thesis, Universitat de València (unpublished).

Verdú, F.J., Royo-Torres, R., Cobos, A. \& Alcalá, L. 2015. Perinates of a new species of Iguanodon (Ornithischia: Ornithopoda) from the lower Barremian of Galve (Teruel, Spain). Cretaceous Research, 56, 250-264; doi: 10.1016/j. cretres.2015.05.010.

Verdú, F.J., Godefroit, P., Royo-Torres, R., Cobos, A. \& Alcalá, L. 2017. Individual variation in the postcranial skeleton of the Early Cretaceous Iguanodon bernissartensis (Dinosauria: Ornithopoda). Cretaceous Research, 74, 65-86; doi: 10.1016/j.cretres.2017.02.006.

Verdú, F.J., Royo-Torres, R., Cobos, A. \& Alcalá, L. 2018. New systematic and phylogenetic data about the early Barremian Iguanodon galvensis (Ornithopoda: Iguanodontoidea) from Spain. Historical Biology, 30, 437-474; doi: 10.1080/08912963.2017.1287179.

Weishampel, D.B., Jianu, C.M., Cziki, Z. \& Norman, D.B. 2003. Osteology and phylogeny of Zalmoxes (n. g.), an unusual ornithopod dinosaur from the latest Cretaceous of Romania. Journal of Systematic Paleontology, 1, 123-143; doi: 10.1017/S1477201903001032.

Winkler, D.A., Murry, P.A. \& Jacobs, L.L. 1997. A new species of Tenontosaurus (Dinosauria: Ornithopoda) from the Early Cretaceous of Texas. Journal of Vertebrate Paleontology, 17, 330-348; doi: 10.1080/02724634.1997.10010978. 
